Discussion Paper No. 98-16

Socio-economic and demographic factors of crime in Germany: Evidence from panel data of the German States

\author{
Horst Entorf \\ Hannes Spengler
}




\section{Non technical summary}

The recent interest in the economics of crime has been stimulated by the dramatic increase in crime rates in the western world on the one hand, and by recent demographic and socioeconomic problems like youth unemployment, migration and increasing inequality on the other. Our study is based on the traditional BeckerEhrlich deterrence model, but we analyse the model in the face of currently discussed crime factors. Several new features are added to the existing literature.

1) Evidence from a panel of the German Laender (states) allows us to explore the different experiences in highly and sparsely populated areas. Moreover, it enables us to look at differences between East and West Germany.

2) Since unemployment can aggravate the probability of being in a young group with "dangerous" social interactions, we estimate the impact of being young and unemployed.

3) Demographic factors like urbanisation and population density effects are taken into account. Moreover, we are trying to shed some light on the validity of the popular argument that the number of foreigners is responsible for growing German crime rates.

4) We add a new relative income variable that might explain crime due to a lack of legal income opportunities ("envy" effects).

5) The impact of unemployment is divided into the investigation of overall unemployment and youth unemployment effects.

6) Our paper breaks up aggregate crime into 8 crime categories. Thus, we are in the position to separate property crime, which might be more directly related to the rational offender, and crime against the person.

7) Our estimation strategy is based on static and dynamic panel econometrics/criminometrics.

Our results confirm the deterrence hypothesis for crime against property (i.e. higher clear-up rates reduce crime against property), but only weak support can be observed for crime against the person. Economic variables that are used to measure legal and illegal income opportunities perform well in estimations for crime against property. Absolute income turns out to be a measure of illegal rather than legal income opportunities (i.e. higher income is associated with higher crime rates). Results based on relative income show that a widening income gap with respect to richer regions increases the probability of delinquent behaviour. Thus, growing inequality seems to be an important factor of crime. Demographic factors reveal important and significant influences. As usually found in the literature, we observe higher crime rates in highly urbanized areas. Moreover, we confirm the ambigous 
result for general unemployment. However, being young and unemployed increases the probability of committing crimes. Additionally, also simply being young aggravates the danger of getting into the bad company of a group with harmful social interactions. Interpreting the influence of the aggregate share of foreigners is difficult in aggregate studies and can only be tentative. Our results suggest that the share of foreigners in Germany is positively associated with crime against property, in particular theft. For all other types of crime, the effect is not clear or insignificant. As regards crime in the eastern and western part of Germany, there remains a higher crime rate in the east, even after controlling for differences in legal and illegal income opportunities and other factors of crime. The reason for this is not clear. Possibly, prosecution of crime and administration of justice are still organized inefficiently in eastern Germany. An other explanation might be that the newly gained freedom has led to (temporarily?) higher violation of social norms. However, a reasonable explanation of the east-west crime differential would need further research.

\begin{abstract}
Our study is based on the traditional Becker-Ehrlich deterrence model, but we analyse the model in the face of currently discussed factors of crime like demographic changes, youth-unemployment and income inequality. We use a panel of the German Laender (states) that allows us to exploit different experiences in densely and sparsely populated areas as well as in East and West Germany. Our results are based on static and dynamic panel econometrics/criminometrics. They confirm the deterrence hypothesis for crime against property. Only weak support can be observed for crime against the person. Economic and demographic factors reveal important and significant influences. Being young and unemployed increases the probability of committing crimes.
\end{abstract}

Key words: Crime, deterrence, socio-economic factors, demographics, income opportunities, panel data

JEL Classification: J19, K42 


\title{
Socio-economic and demographic factors of crime in Germany: Evidence from panel data of the German States
}

\author{
Horst Entorf* and Hannes Spengler** \\ *Universität Mannheim, Germany and Universität Würzburg, Germany \\ **Zentrum für Europäische Wirtschaftsforschung (ZEW), Germany
}

\author{
February 1998 \\ (this version: 20 April 1998) \\ Horst Entorf \\ Universität Würzburg, Institut für Volkswirtschaftslehre, \\ Sanderring 2, 97070 Würzburg, Germany \\ Tel.: +49/931/31-2953, Fax: +49/931/31-2600, \\ E-mail: horst.entorf@mail.uni-wuerzburg.de \\ Hannes Spengler \\ Zentrum für Europäische Wirtschaftsforschung GmbH (ZEW), \\ P.O.Box 1034 43, 68034 Mannheim, Germany \\ Tel.: +49/621/1235-284, Fax. +49/621/1235-225, \\ E-mail: spengler@zew.de
}

\section{Acknowledgement}

We are grateful to Wolfgang Franz, Herbert S. Buscher, Friedhelm Pfeiffer and to the participants of the meeting of the "Ökonometrischer Ausschuß des Vereins für Socialpolitik" in Rauischholzhausen 1998 for helpful comments and suggestions. We thank Carsten Baumann for the translation of appendix A1 and Nancie Carollo for proof-reading. Moreover, we thank Tülün Efe for research assistance. 


\section{Introduction}

Economic contributions in the area of crime started about 30 years ago. Prior to 1968 , offenders were regarded as deviant individuals with atypical motivations. The theory of crime was largely composed of recommendations made by sociologists, psychologists, criminologists, political scientists and law professors that were not based on rigorous empirical investigation, but on beliefs about concepts like depravity, insanity and abnormality.

During the late 1960's, economists turned their attention to the field of criminology. The stimulus was Becker's (1968) seminal paper on "Crime and Punishment". Becker's theory of deterrence is an application of the general theory of rational behaviour under uncertainty. The model predicts how changes in the probability and severity of sanctions may affect expected payoffs and thus the "supply" of crime.

Becker's theoretical work was the stimulus for Ehrlich's (1973) empirical investigations. He extended Beckers's work by considering a time allocation model. The assumption of fixed leisure time requires that the remaining time is allocated to legal and illegal activities. If legal income opportunities are scarce, then the time allocation trade-off predicts that crime becomes more likely. Since legal income opportunities can be measured by abilities, family income, human capital, and other socio-demographic variables (age, race, gender, urbanization, etc.), predictions of the Ehrlich model can be tested empirically.

The bulk of empirical studies uses the Becker-Ehrlich model to estimate the effect of deterrence, measured by the probability and severity of punishment, and of benefits and costs of legal and illegal activities on crime. In most studies, the effect of deterrence variables (clearance or conviction rates, length of sentence, fines) are found to be more or less negative, whereas income variables reveal no systematic effect on crime (see Eide, 1994, 1997, for excellent surveys). This ambiguity reflects the fact that income represents benefits not only for legal activities, but also for illegal ones; therefore, a high number of rich people produce a more profitable target for crimes. As a result, the income measure may be positively correlated with crime rates.

After some time of relative silence with only a few major contributions in the eighties, the last few years witness a vitalization of the "Economics of Crime" (Eide, 1994, Grogger, 1995, Dilulio, 1996, Ehrlich, 1996, Freeman, 1996, Glaeser, Sacerdote and Scheinkman (1996), to name only a few). Modern studies have been stimulated by the dramatic increase of crime rates in western countries on the one hand, and by recent social and economic problems like unemployment, in particular youth unemployment, migration and increasing income inequality on the other. The 
focus of these contributions has changed from the pure testing of the deterrence hypothesis to the analysis of socio-economic and demographic crime factors.

Our paper is in the spirit of the traditional Becker-Ehrlich deterrence model, but we analyse the hypothesis in the face of currently discussed crime factors. Several new features are added to the existing literature:

German data: We test the Becker-Ehrlich deterrence hypothesis using German data (for earlier studies see Entorf, 1996 and Spengler, 1996). Evidence from a panel of the Laender (the German states) allows us to exploit the very different experiences in densely populated areas such as Berlin and Hamburg (which is counted as a state of its own, a so-called "Stadtstaat", i.e. "city-state") and sparsely populated areas such as Lower Saxony. Moreover, it enables us to look at differences between East and West Germany.

Demographic factors: Simple descriptive statistics reveal that people under 21 years of age are responsible for about $28 \%$ of total offenses. However, the reason for higher crime rates might be that they are just poorer than other age groups. Controlling for income and other economic variables, we can test the "pure" effect of being young. Since unemployment can aggravate the probability of being in a young group with "dangerous" social interactions, we estimate the impact of being young and unemployed.

Crime statistics generally exhibit a positive correlation between city size and crime rates. For the United States Glaeser and Sacerdote (1996) find that $45 \%$ of the crime differential between cities and non-cities is due to less intact families, 26\% may be explained by higher illegal income opportunities and $12 \%$ by the lower probability of arrest. In our investigation, urbanization and population density effects on the crime rate are also taken into account.

Finally, we are trying to analyse the popular argument that the number of foreigners is responsible for growing crime rates. Since East Germany has much lower rates of foreigners, we hope to find some evidence from East/West comparisons.

Evolvement of relative income: As mentioned above, the impact of income on crime is not clear. We add a new relative income variable that might help to clarify the situation. The new variable measures relative wealth that might explain crime based on "envy" effects.

Unemployment and youth unemployment: Unemployment generally seems to have only minor effects. We are going to test if this hypothesis also holds true for Germany. In particular, we divide the analysis into the investigation of overall unemployment and youth unemployment effects. 
Several types of crime: Studies based on aggregated data have been critizised. This paper breaks up aggregate crime into 8 crime categories. ${ }^{1}$ Thus, we are in the position to separate property crime, which might be more directly related to the rational offender, and crime against the person.

Static and dynamic estimation strategies: Our estimation strategy is based on static and dynamic panel econometrics/criminometrics. The dynamic model is based on the error-correction mechanism so that we can separate the long-run deterrence behaviour from short-run adjustments due to disequilibrium situations, which, for instance, might arise due to temporarily higher clear-up rates.

Our paper is organized as follows. Chapter 2 describes the development of crime and of potential factors of crime in Germany. In Chapter 3, we present the basic model and estimation methods. After introducing the data in Chapter 4, results are reported and interpreted in Chapter 5. Chapter 6 concludes.

1 The choice of categories is limited by the availability of data. There are no other categories providing data on clear-up rates (see Polizeiliche Kriminalstatistik, 1996). 


\section{Crime and potential factors of crime}

In this section we provide an extensive discussion and descriptive analysis of crime and the potential factors of crime in Germany. The variables of interest are depicted over time and between observational units. Analysing the crime statistics and thus learning about regional differences in the incidence of crime and about the sociodemographic structures of the offenders leads to a better understanding of the factors that may prevent or foster crime.

With only a few exceptions criminal prosecution falls in the responsibility of the Laender. This is a source of heterogeneity that makes it suitable to choose the Laender as observational units in our descriptive and econometric analysis of crime. Apart from the investigation of the states we have a close look at the federal level. Moreover, we carry out comparisons between East and West Germany under special consideration of the city-states. Our exclusive source of crime-data is the annual crime reports of the German Federal Criminal Police Office ("Bundeskriminalamt"). ${ }^{2}$

It is important to mention that all empirical investigations of crime that are based on official statistics have at least one serious shortcoming: the statistics display not the real intensity of crime but only the size of crime known to the police. How large the share of unreported crimes is depends heavily on the type of crime. Generally speaking less serious crimes have a lower probability of being reported to the police than more serious crimes. In addition, the general reporting-propensity of citizens and the level of clear-up efforts by the police play an important role for the number of unrecorded cases. ${ }^{3}$

\subsection{Evidence from the German Crime Statistic}

6.64 Mio. crimes have been registered by the German police in 1996 from which 5.24 Mio. took place in West (including East Berlin) and 1.39 Mio. in East Germany (not including East Berlin). Expressed in rates these numbers mean that there have been approximately 8 offenses per 100 inhabitants in the West and a bit less than 10 offenses per 100 citizens in East Germany. Figure 1 depicts the development of the general crime rate in West Germnay for the past 30 years. There has been a steady increase in West Germany's crime rate from 3 crimes/100 persons in 1963 to 7 crimes/100 persons in 1983. The West German crime rate reached an all-time high in 1993 with a few more than 8 crimes/100 persons. Since 1994 the

\footnotetext{
${ }^{2}$ The Bundeskriminalamt (BKA) is the information office of the Police Offices of the Laender. It is also directly responsible for combatting organized crime and terrorism.

${ }^{3}$ In a discussion with an offical of the BKA we were told that research on the number of unrecorded crimes in a big German city yielded one district with a share of unrecorded thefts of approximatly $80 \%$.
} 
crime rate remains about the same. In East Germany with a crime rate of approximately 10 crimes/100 persons in the last four years the situation is even more serious. Compared with other countries of the EU, German crime rates are neither very high nor very low. ${ }^{4}$

Figure 1: General crime rates in West Germany (1963-1996) and East Germany (1993-1996)

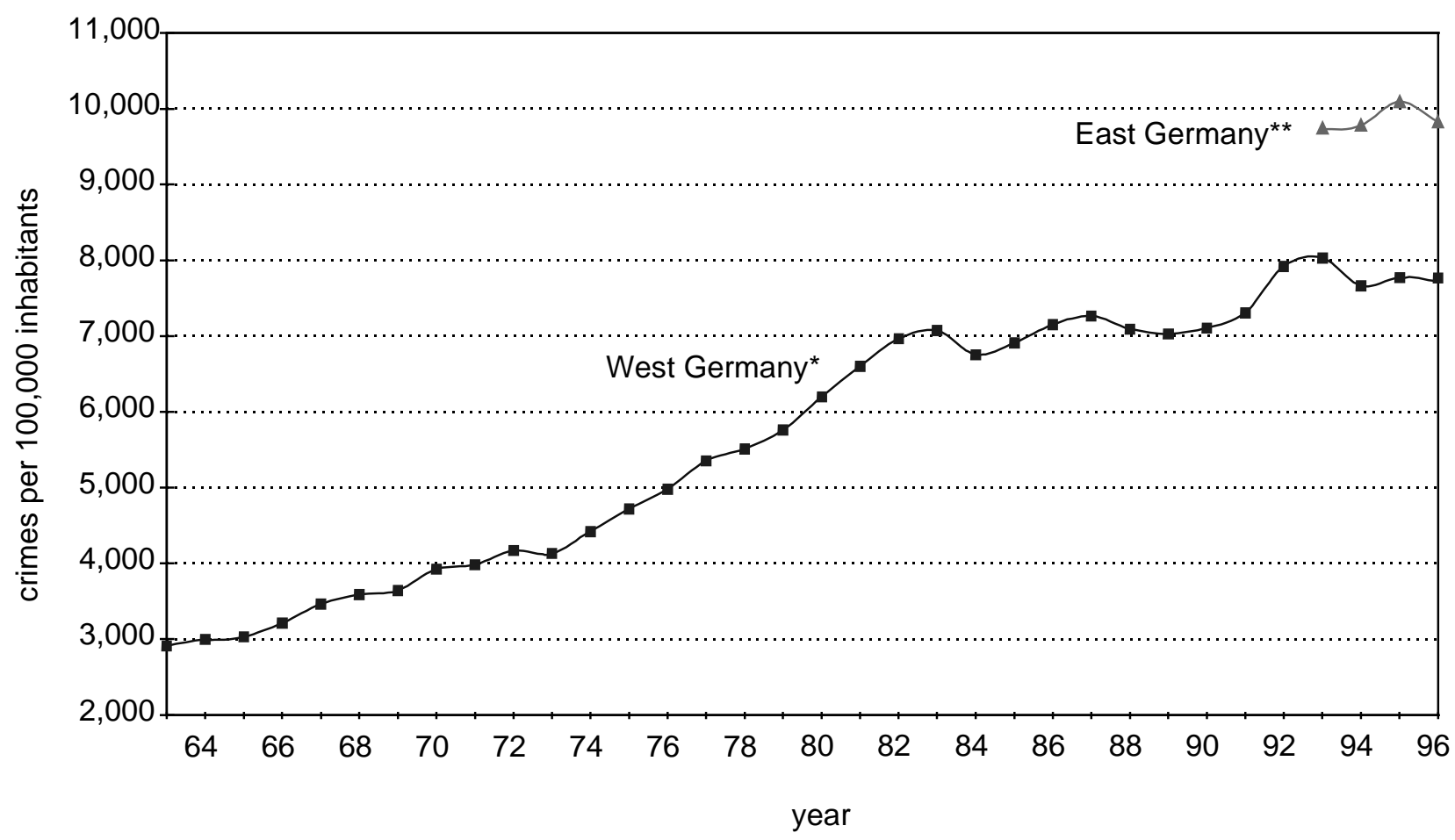

Source: various issues crime statistics of the German Federal Criminal Police Office (Bundeskriminalamt) *including East Berlin after 1990, **not including East Berlin

Regarding Figure 1, two questions can be posed: first, why did crime become thus stronger in West Germany during the last three decades? Second, why is there more crime in East than in West Germany? We hope to shed some light on these questions in the proceeding of our article. Knowing that the general crime rate rose dramatically is one factor. The other important thing to know is which crime categories are responsible for this growth. Table 1 provides an answer to this question. Since theft is the (quantitatively) most important crime category with a share of all crimes bigger than 55\%, it was the increase of this offense that drove the growth of the overall crime rate.

Since total theft experienced a growth of about $74 \%$ in the period from 1975 to 1996, other offenses also increased significantly. The number of environmental offenses was eight times higher in 1996 than 20 years ago, the number of drug offenses was six times higher in 1996, robberies, total assaults and frauds at least

${ }^{4}$ The highest EU crime rate in 1994 was reported for Sweden with 12 crimes/100 inhabitants and the lowest for Spain with 1.7 crimes/100 inhabitants (source: The Fifth United Nations Survey of Crime Trends and Operations of Criminal Justice Systems). 
doubled. The only crime categories that show a decrease are murder and manslaughter, and rape.

Table 1: Development of selected offenses in West Germany

\begin{tabular}{|c|c|c|c|c|c|c|}
\hline \multirow[b]{2}{*}{ Crime Category } & \multicolumn{3}{|c|}{1975} & \multicolumn{3}{|c|}{$1996^{*}$} \\
\hline & $\begin{array}{l}\text { Cases, } \\
\text { absolute } \\
\text { numbers }\end{array}$ & $\begin{array}{c}\text { Cases per } \\
100,000 \\
\text { inhabitants }\end{array}$ & $\begin{array}{c}\text { Share } \\
\text { of all } \\
\text { crimes }\end{array}$ & $\begin{array}{l}\text { Cases, } \\
\text { absolute } \\
\text { numbers }\end{array}$ & $\begin{array}{c}\text { cases per } \\
100,000 \\
\text { inhabitants }\end{array}$ & $\begin{array}{c}\text { Share } \\
\text { of all } \\
\text { crimes }\end{array}$ \\
\hline Murder and manslaughter & 2,908 & 4.7 & 0.1 & 2,839 & 4.2 & 0.1 \\
\hline Rape & 6,850 & 11.1 & 0.2 & 5,373 & 7.9 & 0.1 \\
\hline Robbery & 20,362 & 32.9 & 0.7 & 55,010 & 81.1 & 1.0 \\
\hline $\begin{array}{l}\text { Dangerous and Serious } \\
\text { Assault }\end{array}$ & 50,274 & 81.0 & 1.7 & 85,040 & 126 & 1.5 \\
\hline $\begin{array}{l}\text { Assault (not dangerous or } \\
\text { serious) }\end{array}$ & 65,674 & 106 & 2.2 & 164,369 & 243 & 3.1 \\
\hline $\begin{array}{l}\text { Theft without aggravating } \\
\text { circumstances }\end{array}$ & 864,849 & 1,399 & 29.6 & $1,269,521$ & 1,877 & 23.5 \\
\hline $\begin{array}{l}\text { Theft under aggravating } \\
\text { circumstances }\end{array}$ & $1,044,569$ & 1,689 & 35.8 & $1,558,582$ & 2,304 & 31.8 \\
\hline Fraud & 209,841 & 339 & 7.2 & 556,888 & 823 & 9.8 \\
\hline Damage to property & 213,746 & 458 & 8.3 & 474,576 & 702 & 9.4 \\
\hline Drug offenses & 29,805 & 48.2 & 1.0 & 179,754 & 266.0 & 2.8 \\
\hline Environmental offenses & 3,445 & 5.6 & 0.1 & 30,109 & 45.0 & 0.6 \\
\hline
\end{tabular}

Source: BKA, 1975, 1996

*including East Berlin

Contrary to current suggestions given by mass media, violent crimes (murder and manslaughter, rape, robbery, dangerous and serious assault) are only of minor quantitative importance. They accounted for only $2.7 \%$ of all reported crimes in 1996. Considering only the most serious crimes (i.e. murder and manslaughter, and rape) the share is $0.2 \% .^{5}$ The bulk of crimes are offenses against property, which account for at least $75 \%$ of all crimes. In spite of this, it should be noted that the propensity to violence has increased in the last 20 years (see robbery and assault).

${ }^{5}$ If the the number of unrecorded cases could be taken into account this share would be even smaller since serious crimes tend to be reported more frequently than other offenses. 
Figure 2 displays the development of the general crime rate (the bold lines in the upper half of the figure) for the West German Laender in the period 1975-1996 ${ }^{6}$. It is striking that the very densely populated city-states of Berlin, Bremen and Hamburg are by far the most criminal Laender in West Germany. It is surprising that Schleswig-Holstein, as a state with a rather low population density, exhibits the highest crime rate of all non city-states in 1996. Furthermore, it is this state that experienced the highest relative growth in the general crime rate over the last 20 years. Generally speaking, crime rates are low in the southern part of West Germany (Baden-Wuerttemberg, Bavaria, Saarland and Rhineland-Palatinate) and high in the north (North Rhine-Westphalia, Lower Saxony and Schleswig-Holstein). Since northern states are relatively poor in comparison to southern states we find it appealing to consider measures of relative and absolute wealth as potential factors of crime.

Figure 2: General crime and clear-up rates in the West German states 1975-1996 (West Berlin 1975-1989*)

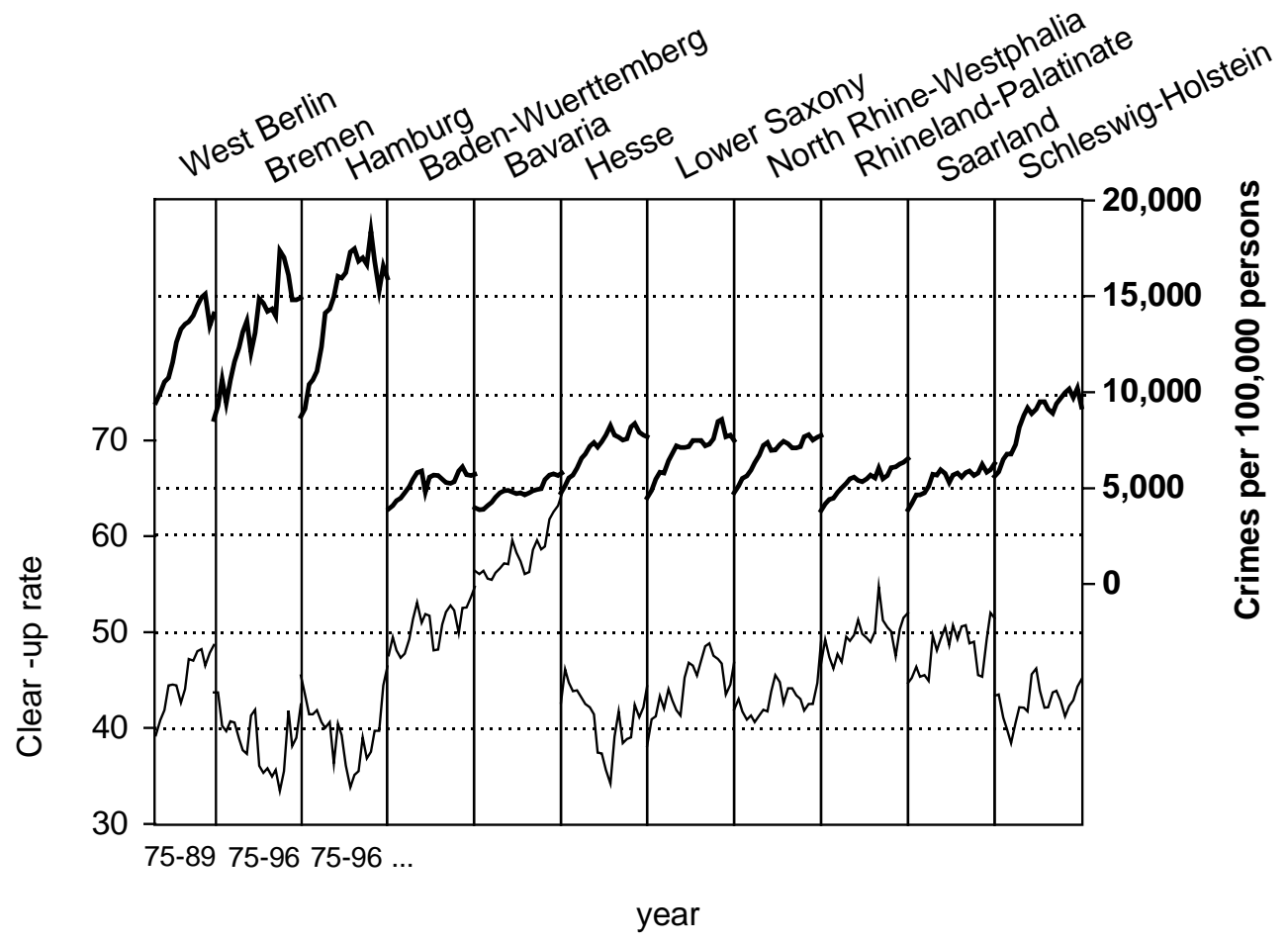

Source: various issues crime statistics of the German Federal Criminal Police Office (Bundeskriminalamt) *After 1989 the statistics contain only information about unified Berlin.

After investigating the incidence of crime it is straightforward to analyze the sociodemographic properties of the offenders. From 100 suspects, approximately 75 are male, so gender seems to play an important role in the crime-deciscion. Age is very important, since $40 \%$ of all crimes in 1996 were comitted by offenders of less than 25 years of age.

${ }^{6}$ (West) Berlin is only considerd until 1989 since crime data for West and East Berlin are not displayed separatly in the years after German Unification. 
Figure 3 puts age and gender in relative context to crime. It displays the number of offenders in a certain age-gender group in relation to the absolute size of this agegender group in the population. It is striking that in the groups $16<18$ (at least 16 and at most 17 years of age) and $18<21$ for males every ninth person has been suspect of crime. Thus, young men are the most criminal age-gender group in relation to their population share. For example, while the population share of men aged at least 14 and at most 24 years has been $5.7 \%$ in 1996 their share of all suspects has been $27 \%$. According to this evidence, it seems reasonable to use a variable that measures the population's share of young men in our econometric investigations. In contrast, a gender-variable would be less appropriate because of lacking variation over time and observational units.

Figure 3: German suspects of crime per 100,000 inhabitants of their age-group

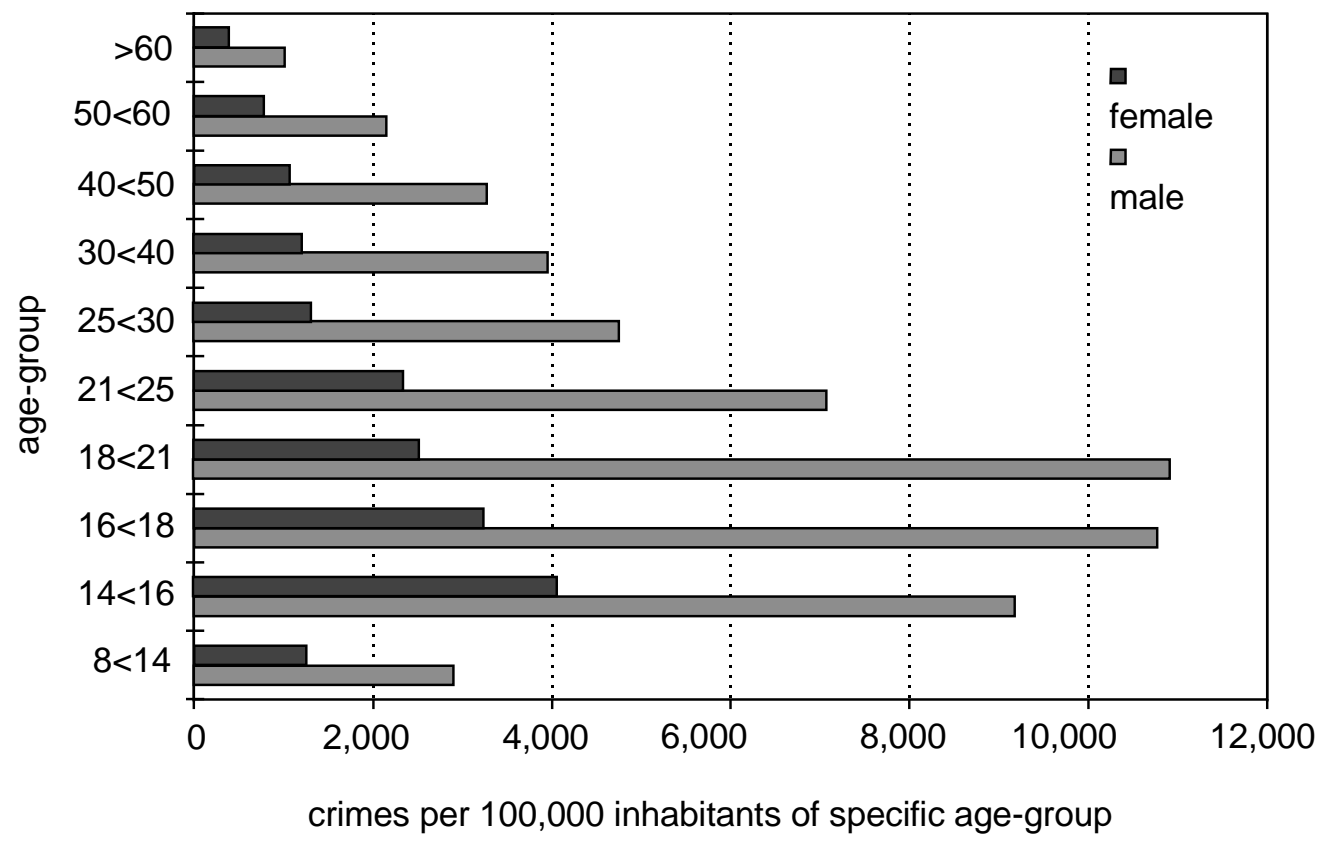

Source: 1996 crime statistics of the German Federal Criminal Police Office (Bundeskriminalamt)

Finally, it has to be mentioned that a high percentage of crimes in Germany are committed by foreigners. In 1996, approximately $28 \%$ of all suspects were foreigners whereas their poulation-share equaled $9.0 \%$ only. This divergence gives rise to the use of a foreigner-variable in our estimations.

\subsection{What prevents or fosters crime?}

In his discussion of the determinants of crime, Eide (1997) differentiates between three categories of variables that are commonly used in criminometrics - deterrence, economic, and norm and taste variables. While the first and the second group of variables are theoretically underpinned by the conventional economic crime theory (see for example Becker, 1968 and Ehrlich, 1973) norm and taste variables are not 
thoroughly discussed. It is true, though, that some norm and taste variables can be interpreted in the sense of legal and/or illegal income opportunities and would thus be partly covered by conventional theories.

Recent contibutions from economists explicitly model the influence of social factors on the crime decision. Glaeser, Sacerdote and Scheinkman (1996) and Akerlof (1997) investigate the importance of social interactions between individuals for the incidence of crime. Williams and Sickles (1997) extend the existing theory by considering the consequences of social capital formation over the life-cycle on the crime decision. These papers make an important effort towards an interdisciplinary crime research.

\subsubsection{Deterrence}

Deterrence variables i.e. clear-up rates, conviction rates and severity of punishment are important determinants of the expected utility that potential offenders can yield from crime, these variables have been the focus of early studies. Admittedly, this focus changed in the eighties and nineties to economic and sociodemographic factors, however, deterrence variables should always be present in criminometric studies.

In his theory, Becker (1968) uses the probability of conviction and the severity of punishment as exogenous variables in the supply-of-offenses function. In his and in most other theoretical articles, the effect of deterrence variables on crime is clear. A higher probability of conviction/severity of punishment leads to a reduction in the expected utility from crime and, therefore, less offenses will be commited. As a result, we expect negative signs for the deterrence variables in our estimations.

Unfortunately, we are only able to use the clear-up rate in our econometric specifications, since this is the only deterrence variable for Germany that is available on the state-level. In contrast to this, Wolpin (1978) in his empirical study of crime in England and Wales uses five different deterence variables:

- the proportion of crimes cleared by the police (clear-up rate)

- the proportion of those arrested who either plead guilty or are convicted (conviction rate)

- the proportion of the guilty who are imprisoned (imprisonment rate)

- the proportion of the guilty who are placed on recognizance (recognizance rate)

- the proportion of the guilty who are fined (fine rate)

- the average length of the court imprisonment sentence for those imprisoned (average sentence)

To our knowledge this study is the only one that applies such a complete set of deterrence variables. The majority of empirical investigations use at most two 
deterrence variables, one of which is the severity of punishment ${ }^{7}$ and the other the probability of being caught or convicted.

Figure 4 depicts the clear-up rates for reported aggregated crime in West and East Germany. In the West, the rate was highest in 1963 with approximately $55 \%$. In the following 10 years, it fell to $45 \%$ and then moved sideways until 1992 (with some fluctuations in the eighties). After 1992, the rate grew continuously and, in 1996, reached the highest level since 1970. East Germany's clear-up rate started at a very low level $(33,6 \%)$ and then increased strongly until $1996(44,2 \%)$. In spite of this increase it has still not reached the West German level.

Figure 4: General clear-up rates in West Germany (1963-1996) and East Germany (1993-1996)

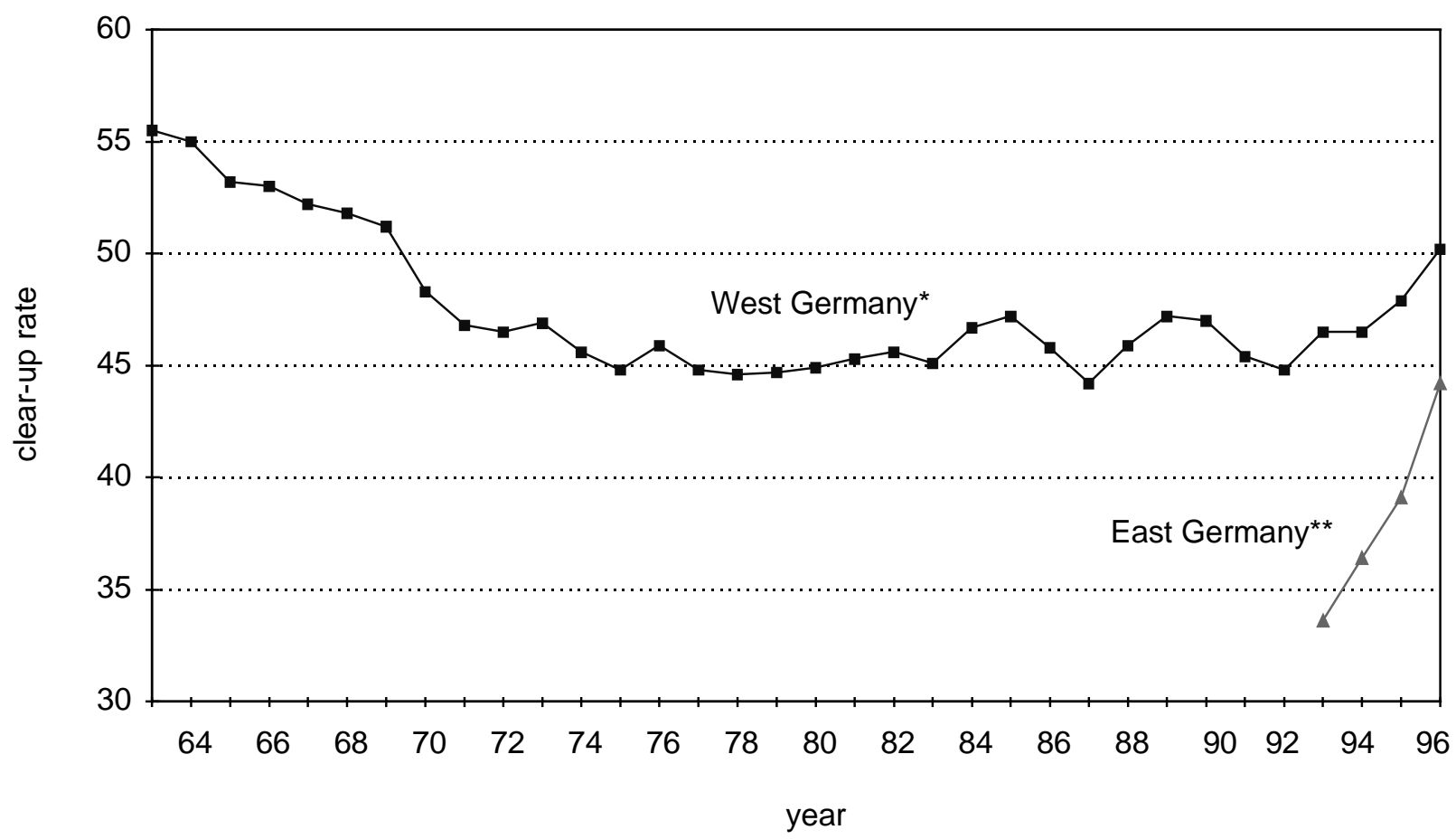

Source: various issues crime statistics of the German Federal Criminal Police Office (Bundeskriminalamt) *including East Berlin from 1990 on, ** not including East Berlin

Comparing Figures 1 and 4 it is striking that crime incidence and clear-up rates are obviously negatively related. West Germany exhibits higher clear-up rates than East Germany and at the same time less crime. This evidence can also be drawn from a comparison of crime and clear-up rates for the Laender in Figure 2 (the clear-up rates are presented as fine lines in the lower part of the diagram).

${ }^{7}$ It should be mentioned that clear measures of the severity of punishment for aggregated crime or special crimes can not be easily obtained since most crimes are not exclusively sanctioned by either fines or imprisonment. As a consequence, a suitable sanction variable for macroeconometric studies requires the conversion of time (the dimension of imprisonment) in money (the dimension of fines) or vice versa. 
Baden Wuerttemberg and Bavaria have higher clear-up rates and lower crime rates than all other states. On the other hand, states with low clear-up rates like Bremen, Hamburg and Schleswig-Holstein show a higher incidence of crime. In the context of our previous discussion, the meaning of the graphically depicted negative correlation is straightforward. The higher risk of being detected by the police makes offending in Baden-Wuerttemberg ceteris paribus less attractive than in the citystates.

Unfortunately, the reality is not as simple as it seems to be, since there is presumably no clear causality-relation between clear-up rate and crime rate. In other words, it is likely that, apart from the influence of the clear-up rate on the crime rate, there is also an influence in the inverse direction. There may be two sources for short-run simultaneity. First, if crime rises and the number of police stays the same (for example due to budgetary limitations), police tend to be overloaded and thus the clear-up rate falls (while the absolute number of cleared-up offenses stays the same). This would lead to an overestimation of the effect of interest (thus, from the clear-up rate on the crime rate). The second potential cause of bias emerges if higher crime rates lead to protests among the population which for instance induces politicians to hire new policemen. As a result, the clear-up rate would rise (at least temporarily). This effect leads to an underestimation of the effect of interest. Because the two potential sources of bias have opposite effects, the joint effect is not evident. However, since we are mainly interested in economic long-run behaviour, potential short-run biases should cancel out in our estimations (note that our panel data has a relatively large time dimension; moreover, we use static and dynamic ECM-modelling, see Chapter 3.2).

\subsubsection{Legal and illegal income opportunities}

The economic approach to crime builds on the appealing assumption that "offenders, as members of the human race, respond to incentives" (Ehrlich, 1996, p. 43). Incentives determine whether crime is more or less attractive and, thus, more or less likely committed. The deterrence variables discussed above are for example negative incentives in the context of the crime decision. Other straightforward incentives that slow down or foster crime are the legal and illegal income opportunities, which may be approximated by economic variables like total income, income distribution or unemployment. Moreover, legal wages represent the opportunity costs of committing crimes. Grogger (1997) uses this feature of illegal behaviour to explain why the likelihood of delinquency typically increases with age until the late teens and then declines.

Since illegal income opportunities can not be directly measured, a proxy is needed. Ehrlich (1973) proposes the mean family income as such a measure. He argues that higher income means a higher level of transferable assets in the community and thus more lucrative targets for potential criminals. Other authors use the same variable to 
measure legal income opportunities. In this paper we follow Ehrlich, when approximating the illegal income opportunities with the real Gross Domestic Product per capita. The variable is depicted in bold lines in the upper half of Figure 5. Comparing Figures 1 and 5 yields some evidence for the appropriateness of our approximation. The two richest states (Bremen and Hamburg) also have the highest crime rates. This may be due to the fact that crime is particularly rewarding in these rich city-states.

Figure 5: Real GDP per capita in prices of 1991 and relative distance in real GDP per capita from the West German mean for West German states

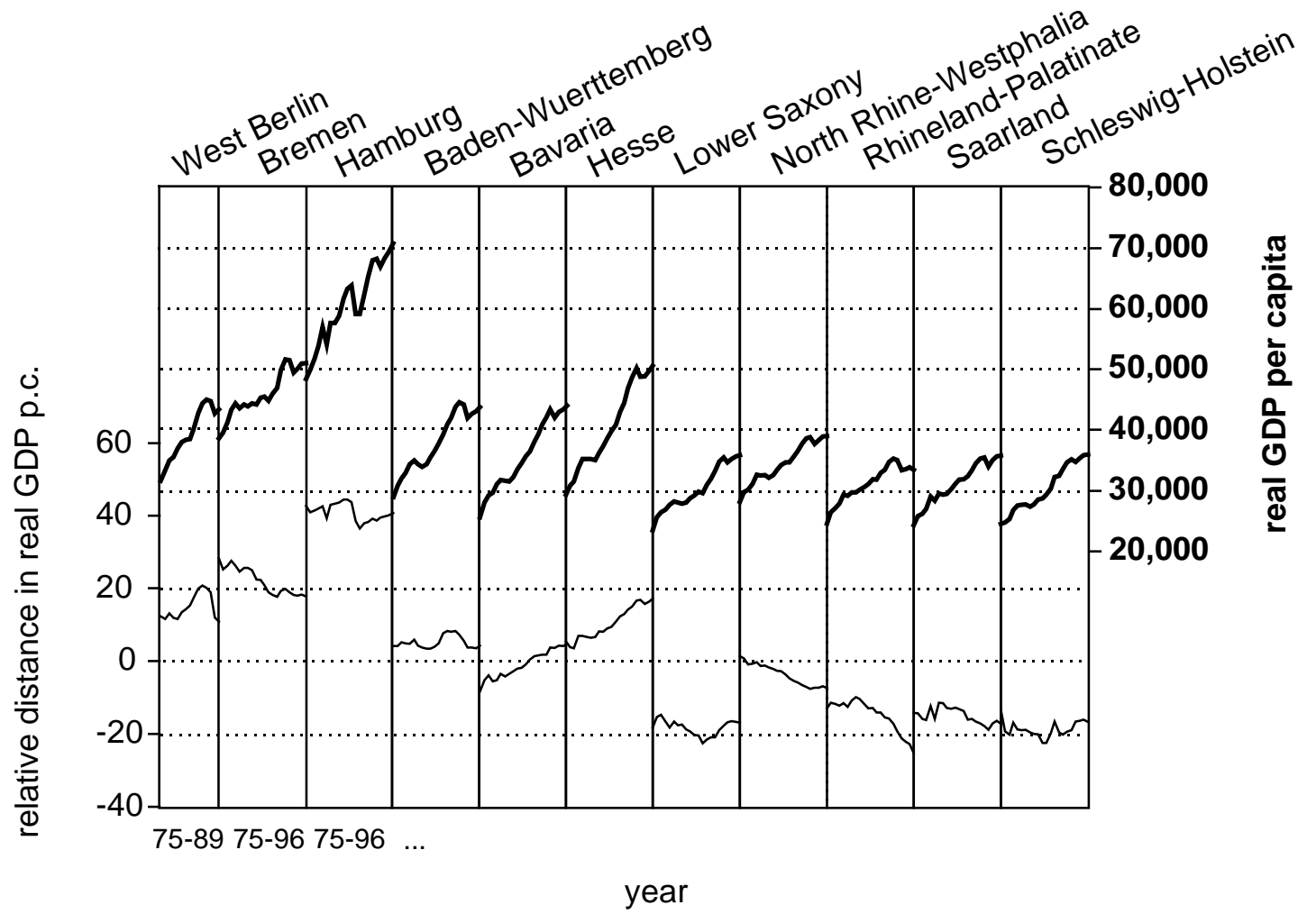

Source: various issues statistics of the Federal Statistical Office of Germany (Statistisches Bundesamt) Whereas the interpretation of absolute income measures is ambiguous, that of relative income measures is more straightforward. A higher income inequality, for instance, may lead to worse legal income opportunities and at the same time to better illegal income opportunities and thus to higher crime incentives for the lower quantiles of the income distribution. For this reason, usual aggregate time series studies often add income inequality as another source of crime. Our relative income variable is depicted in lower half of Figure 5. It measures the percentage distance between a state's income and the mean income over all states (i.e. the federal income). In regions that are better off than the German average, it should be easier to get a well-paid legal job (and vice versa). Thus, ceteris paribus, people in favoured states have less incentives to commit crimes than people in areas poorer than average. 
Since unemployed persons are per definition excluded from the legal income sector, this variable can be as well interpreted as a measure of legal income opportunities. The unemployment rates for the West German Laender are presented in Figure 6. The comparison of Figures 1 and 6 gives the impression that low (high) unemployment is associated with a low (high) incidence of crime (see BadenWuerttemberg, Bavaria, Bremen, Hamburg).

Figure 6: Unemployment rates in the West German states 1975-1996 (West Berlin 1975-1989)

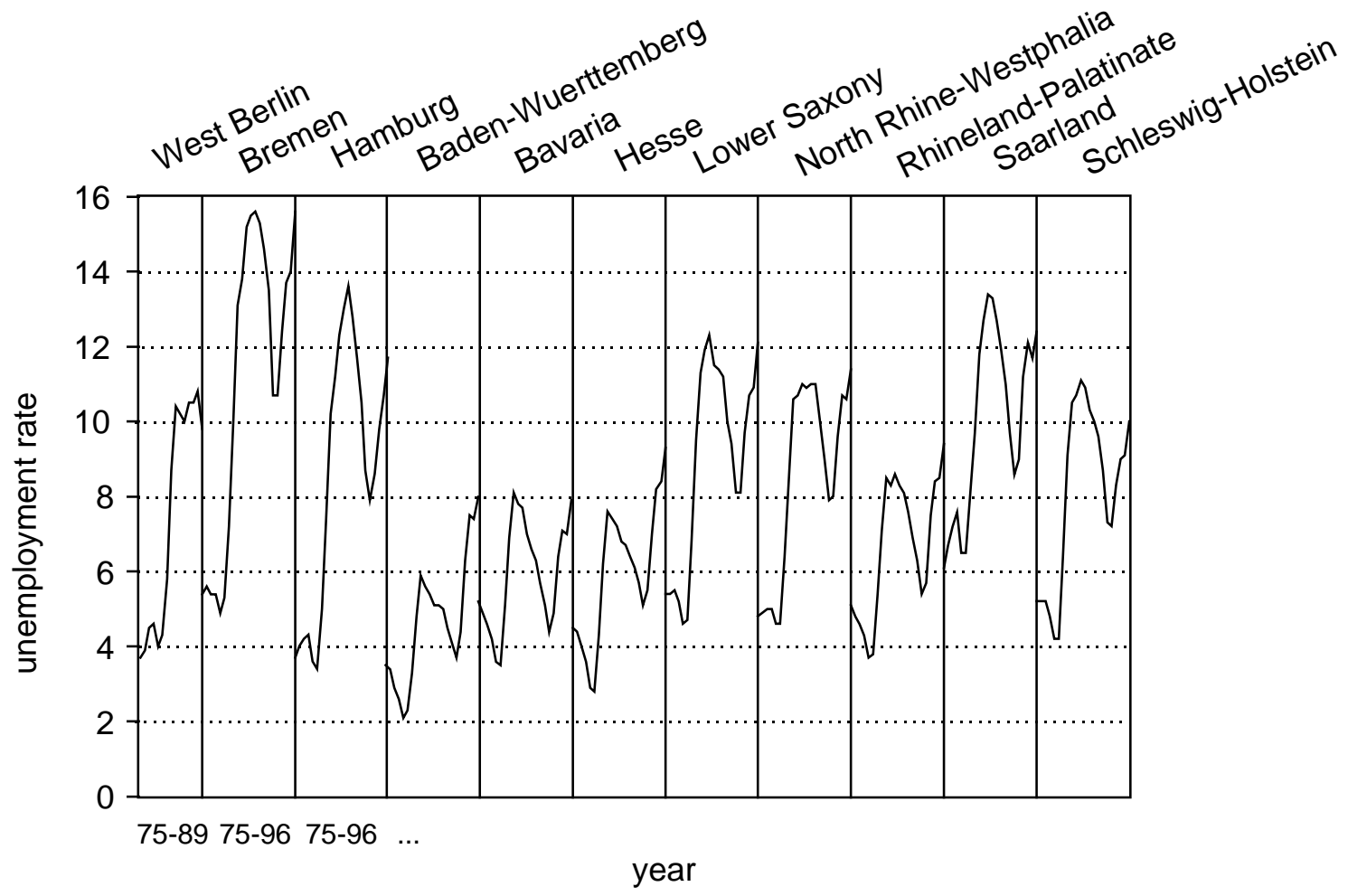

Source: various issues statistics of the Federal Statistical Office of Germany (Statistisches Bundesamt) At this point it should be stressed that all judgements about potential interrelationships between economic, deterrence and other variables that are based on simple descriptive statistics are only preliminary. Whether these first impressions are right or misleading can only be established in the context of our econometric analysis in section 4 .

\subsubsection{Norms, tastes and social interactions}

In the afore-mentioned studies (Glaeser, Sacerdote and Scheinkman, 1996, Akerlof, 1997 and Williams and Sickles, 1997) the effects of social interactions and social capital formation on crime are taken into account. Since norms, tastes and social relations among individuals are certainly important factors for the crime-decision we try to consider them by using sociodemographic variables in our criminometric analysis. 
We include two norm-variables in our estimations that were partly motivated by our descriptive analysis of suspects of crime, but also discussed in the literature (see for example Eide, 1994). They are the percentage of foreigners and the percentage of men aged 15-24 years in the population (foreigner-rate, young-men-rate). Both variables are jointly presented in Figure 7 . How can these variables be interpreted in the context of norms, tastes and crime-augmenting social interactions?

Figure 7: Percentage of foreigners and men aged 15-24 in the population of West German states 1975-1996 (West Berlin 1975-1989)

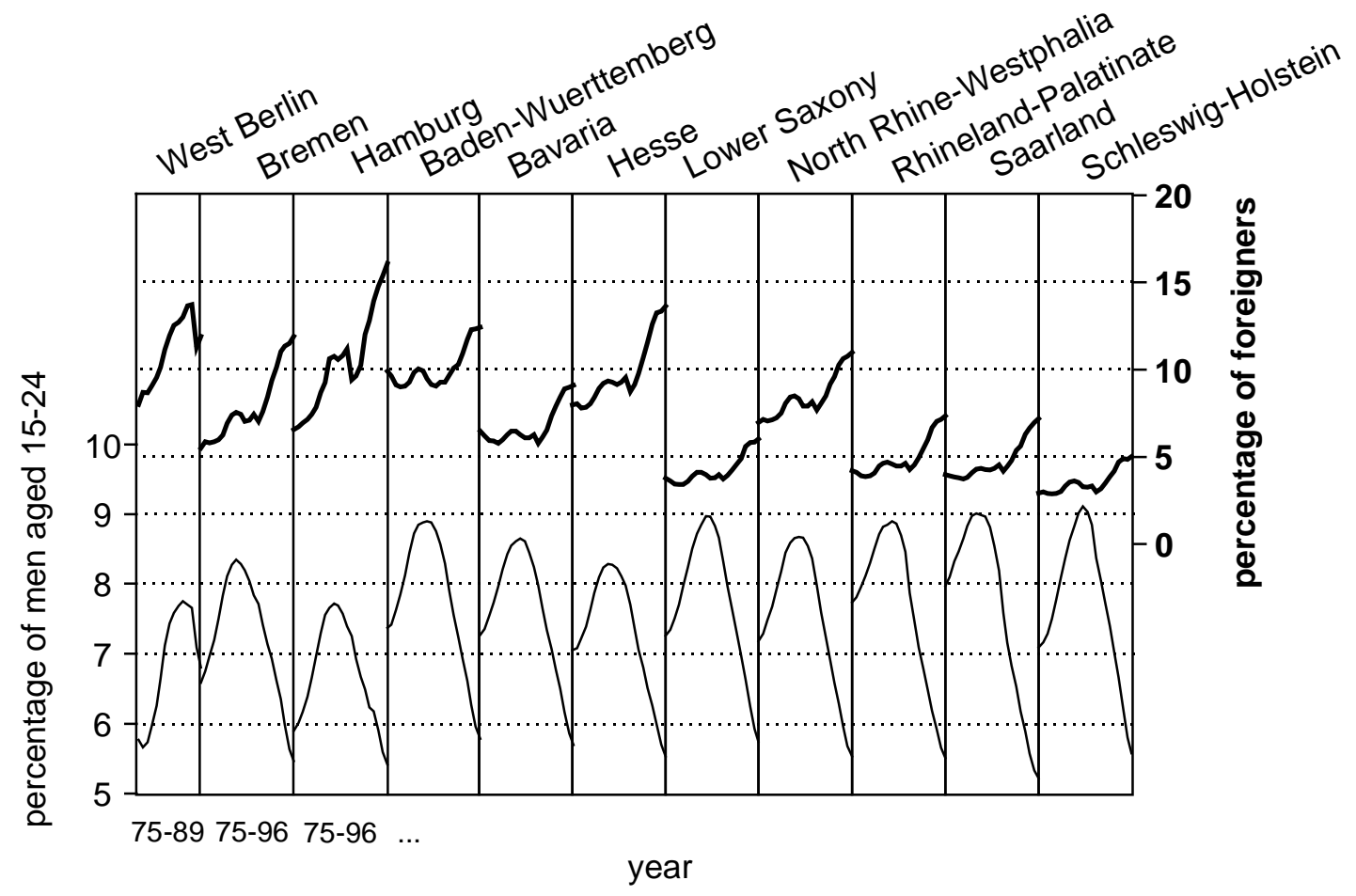

Source: various issues statistics of the Federal Statistical Office of Germany (Statistisches Bundesamt)

Considering youth (young men) first, one might think that in general they do not accept social (crime-averse) norms to the same extent as older people. This may be due to age-specific rebellion or lack of hindsight (see Eide, 1994). Further, young people are in a "better" social and physical position to commit crimes. Thus the threat of loss in reputation and social status when being accused or convicted of a crime is much higher for adults with well-established social networks than for young people (see Eide, 1994). Young men are physically superior to other groups of the population. This means that they have comparative advantages for commiting crimes that require strength and/or speed. Older people are very often married and, therefore, spend their leisure time within their family. Young people in contrast spend much more time in their circle of friends and crowds. This might create dangerous social interactions when initially law-abiding members of a clique begin to imitate the behaviour of the group's delinquent peers (Ploeger, 1997).

There are many reasons why foreigners are over-represented in the group of suspects (see Pfeiffer et al., 1996, for empirical evidence on this point). First, they 
may be more often wrongly suspected than the native population. Second, there are some laws like the foreigner and asylum laws which can by definiton only be broken by foreigners. Third, foreigners who reside in Germany are to a higher percentage young men. Fourth, some foreigners may be in Germany after fleeing their homeland because they were offenders there. Finally, most foreigners come to Germany because they had no economic success in their home country. The latter may be due to factors that foster crime, for example a lack of education. Since, in our econometric specifications, we are interested in the pure crime-effect of being a foreigner in Germany, all the points mentioned above are potential sources of bias. These points should be kept in mind when judging upon the coefficients of the foreigner variable in our estimations.

One of our motivations for using a foreigner variable is its supposed connection with norms, tastes and social interactions. A low adherence to norms may be the consequence of or a reaction to discriminatory tendencies against foreigners by the native population. Moreover, concerning crime-enhancing social interactions, foreigners are presumably more likely to become offenders, since (especially young) foreigners spend more time in cliques.

Apart from norms, tastes and social interactions the young-men and foreigner variables may also be related to deterrence variables, and legal and illegal income opportunities. Young men/people, especially when they are less than 18 years of age and/or first-time offenders, usually are not severely punished. On the other hand, young men/people who are pupils, students or job-beginners with low wages, have relatively low legal income opportunities. The same holds true for foreigners who may have low-paid jobs due to language problems or lack of education. Moreover, the physical advantages of young men increase their illegal income opportunities.

In regard to the crime statistic, gender is obviously an important factor. Less than $30 \%$ of all suspects in Germany are women, a fact that may partly be explained by the social role of women in the society (see Eide, 1994). Statistically, women spend more time with their children and housework. Thus they have less time and less opportunities to commit crimes. Moreover, because of the tendency to impress friends, crime-increasing social interactions seem to be more extensive among men. Apart from the fact that gender is indeed an important factor of crime, its use in regressions of the supply-of-offenses is not meaningful because there is not enough variation in the gender variable nor between observational units nor over time.

Population density is another important determinant of crime. Big cities exhibit much higher crime rates than smaller cities or rural areas. According to their study for the United States, Glaeser and Sacerdote (1996) find that $45 \%$ of the crime premium in cities is due to less intact families in large cities. (26\% may be explained by higher illegal income opportunities and $12 \%$ by the lower probability of arrest.) Families are less intact in metropolitan areas. This fact may again be 
interpreted in the sense of dangerous social interactions. When parents lose influence over their children's behaviour, children are more likely to enter youthgangs. In our econometric analysis, we use dummy-variables to represent the crimeeffect of population density.

The majority of our descriptive analysis of crime and its factors has been carried out on data for West Germany (11 Laender, 1975-1996) alone. Most of our estimations are based on this dataset. The other dataset we use contains West and East German states (16 Laender, 1993-1996). Table 2 gives an impression of the relevant variables in a West-East-German context. The table also contains aggregated information about the city states.

Table 2: Crime and socioeconomic conditions in West Germany, East Germany and the City-States in 1996

\begin{tabular}{|c|c|c|c|}
\hline Variables & "West Germany* & City-States ${ }^{\star \star}$ & East Germany ${ }^{\star \star \star}$ \\
\hline All Crimes per 100,000 inhabitants & 7,768 & 16,520 & 9,828 \\
\hline General Clear-up rate & 50.2 & 44.8 & 44.2 \\
\hline Robberies per 100.000 inhabitants & 81 & 303 & 89 \\
\hline Clear-up rate for Robbery & 46.1 & 36.7 & 53.5 \\
\hline $\begin{array}{l}\text { Thefts under aggravating circumstances } \\
\text { per } 100.000 \text { inhabitants }\end{array}$ & 2,304 & 5,142 & 3,903 \\
\hline $\begin{array}{l}\text { Clear-up rate for thefts under } \\
\text { aggravating circumstances }\end{array}$ & 12.9 & 8.6 & 15.5 \\
\hline Murders per 100.000 inhabitants & 7.9 & 8.0 & 6.0 \\
\hline Clear-up rate for murders & 93.0 & 87.4 & 88.5 \\
\hline $\begin{array}{l}\text { Percentage of foreign citizens in the } \\
\text { population }\end{array}$ & 10.3 & 13.7 & 1.7 \\
\hline $\begin{array}{l}\text { real gross domestic product per capita } \\
\text { in prices from } 1991\end{array}$ & 41,530 & 48,066 & 18,016 \\
\hline unemployment rate & 10,7 & 14,5 & 17,0 \\
\hline $\begin{array}{l}\text { unemployed aged } 24 \text { or younger as a } \\
\text { percentage of all unemployed people }\end{array}$ & 12.9 & 11.3 & 11.1 \\
\hline $\begin{array}{l}\text { percentage of males aged } 15-24 \text { in the } \\
\text { population }\end{array}$ & 5.6 & 5.4 & 6.4 \\
\hline
\end{tabular}

Source: Annual crime statistic 1996 of the German Federal Criminal Police Office (Bundeskriminalamt), anual statistic 1996 of the Federal Statistical Office of Germany (Statistisches Bundesamt), anual labour statistic 1996 of the Federal Employment Service (Bundesanstalt für Arbeit) and own calculations.

*West Germany includes East Berlin. **The city-states are Berlin (West and East Berlin), Bremen and Hamburg. ***East Germany does not include East Berlin. 


\section{Model Specifications and estimation methods}

\subsection{The basic model}

The economics of crime has its origin in the well known and pathbreaking paper on "Crime and Punishment" by Becker (1968). The main purpose of his essay is to answer the question, how many resources and how much punishment should be used to minimize social losses due to costs of crime (damages, cost of apprehension and and conviction). His basic model is based on the assumption "that a person commits an offense if the expected utility to him exceeds the utility he could get by using his time and other resources at other activities" (Becker, 1986, p. 176). ${ }^{8}$ The public's decison variables are its expenditures on police, courts, the size and the form of punishment that help to determine the individual probability of committing a crime. Changing these factors of deterrence means that the expected payoff from crimes and, in turn, the number of offenses will change. Becker calls this relationship between the number of offenses and the amount of deterrence the "supply of offenses".

Becker's theoretical work was extended by Ehrlich (1973). By considering a time allocation model, he motivated the introduction of indicators for legal and illegal income opportunitues. These considerations lead to the basic Becker-Ehrlich specification, which is commonly written in logarithmic form:

$$
\ln O=\alpha+\beta \ln D+\gamma \ln Y+\delta \ln X
$$

where

$O=$ crime rate,

$D=$ deterrence,

$Y=$ income,

$X=$ other influences.

In our specification, as in most applications of the Becker-Ehrlich specification, we measure deterrence by clear-up rates. A minor part of empirical investigations also uses size and form of fines. Both are expected to have negative signs in eq. (1). We

\footnotetext{
${ }^{8}$ Many applications of the Becker model state that the main purpose of his essay was to present a microeconomic model of rational behaviour. This is not true. Though his model is based on the central assumption of Von Neumann-Morgenstern utility which was introduced in a footnote: Becker (1968, p. 177). Becker clearly expresses his motivation by developing "optimal public and private policies to combat illegal behaviour" (Becker, 1968, p. 207).
} 
refrain from testing the effects of varying the severity of punishment, because punishment is mainly based on federal laws.

Our specification also uses two proxies for legal and illegal income opportunities. The first one is the usual indicator (real) GDP per head, which should, according to Ehrlich (1973), measure illegal income opportunities. It should, therefore, have a positive impact on the crime rate. The second one is "relative distance to average income" (measured by ["realGDP/head" - "average real GDP/head"] / "average real GDP/head"). Since we are dealing with panel data, this variable replaces the variable income inequality of aggregate studies. It measures income with respect to incumbents of average income. In a sense, one might interpret such a variable as "envy effect". In the sense of Ehrlich (1973), for relatively poor people below the average, expected income from legal activities is expected to be low, whereas people from above the average have less incentives to commit a crime. Thus, the expected sign in the supply-of-offenses function is negative.

In modern studies "other influences" have reached central attention. They are discussed because of the sustainable growth rates of crime in western countries, and because of recent economic and demographic problems like unemployment, increasing income inequality, high number of foreigners, urbanization and youth unemployment. German case studies are also faced with the problem of East/West adjustments.

Our general specification takes these points into consideration. It can be written as

$$
\ln O=\alpha+\beta \ln p+\gamma_{1} \ln Y^{a}+\gamma_{2} \ln Y^{r}+\delta \ln X,
$$

where

$O=$ crime rate (number of offenses / 100,000 inhabitants),

$p=$ clear-up rate ("probability of being detected"),

$Y^{a}=$ absolute income,

$Y^{r}=$ relative income,

$X=$ unemployment, age, foreigners, urbanization,east-west differentials.

Equation (2) serves as a starting point for our econometric specification. In the sense of Eide (1994), it should be named "criminometric" specification. 


\subsection{The econometric/criminometric specification}

Our data consist of a cross-section of time series from the German Laender. In order to exploit both, the time series and cross-section variation of the data, we use standard panel econometric techniques.

The bulk of our estimates uses the sample period 1975 to 1996 . Thus, the time series dimension is relatively large when compared to the cross-section dimension (Germany is split up into 16 states, 11 states are in West Germany). Moreover, demographic, econometric and criminometric time series show a trend. Thus, we are faced with the potential problem of nonstationarity, though the length of our time series (22 observations) does not allow for serious unit root tests because of the very low statistical power. There are some new efforts of testing for unit roots that exploit the cross section dimension (Levin and Lin, 1992, 1993), however these tests are of limited practical relevance since they assume that under the null hypothesis all times series in the cross section have the same (unit root) parameter. ${ }^{9}$ Not surprisingly, our panel-unit root tests produce ambiguous results. Although most of the variables seem to be stationary, some variables reveal signs of nonstationary $\mathrm{I}(1)$ behaviour.

In order to keep the analysis tractable, we check the robustness of our results by continuing in two steps. First, we run a static regression using the specification presented above. Then, in a second step, we implement the error-correction mechanism, which is well known from dynamic time series analysis. It can be interpreted in both stationary and nonstationary frameworks:

$$
\begin{aligned}
\Delta \ln O= & c+g\left(\ln O_{-1}-\beta \ln p_{-1}-\gamma_{1} \ln Y_{-1}^{a}-\gamma_{2} \ln Y_{-1}^{r}-\delta \ln X_{-1}\right) \\
& +\bar{\beta} \Delta \ln p+\overline{\gamma_{1}} \Delta \ln Y^{a}+\overline{\gamma_{2}} \Delta \ln Y^{r}+\bar{\delta} \Delta \ln X,
\end{aligned}
$$

where $\Delta$ is the difference operator. Deviations from the general equilibrium, i.e. eq. (2), are expected to be corrected next period. Hence, $g$ should have a negative sign. Otherwise, there would be no convergence and the deterrence equation would not be valid. Barred parameters show whether there are significant forces in the short run that might lead to corrections of the crime rate.

We include dummy variables to control for unobserved heterogeneity of the German Laender. Since they are responsible for criminal prosecution, these dummies can cover potential differences in the efficiency and the prefences of state governments. Moreover, in contrast to cross-sectional studies, fixed-effect modelling allows us to control for different shares of unreported crime at the state level (if these do not change over time).

\footnotetext{
${ }^{9}$ We provide panel unit root tests in Table A2.7 in the appendix.
} 


\section{Data}

For our empirical investigations on the supply-of-offenses functions we use two different datasets. The first one (the long panel) is an exclusively West German panel dataset containing all 11 Laender that formed the Federal Republic of Germany prior to the German unification in 1990. The panel is unbalanced because reliable data for the former West Berlin is only available until 1989. All other states are considered from 1975 to 1996.

The second dataset (short panel) contains all 16 Laender that constitute the Federal Republic of Germany now. In the years following the reunification, there were difficulties in the registration of crimes and clear-ups in the five New Laender (that were part of the former German Democratic Republic). For that reason, only a period of four years (1993-1996) can be considered in a crime-related dataset containing all 16 Laender of Germany. Furthermore, it should be mentioned that Berlin, which contained a West and East German part, is treated as a West German state in our empirical analysis. ${ }^{10}$

Table 3 describes all variables that are used in our estimations. All crime and clearup rates are taken from the German Federal Criminal Police Office (Bundeskriminalamt). The choice of crime categories is limited by the availability of clear-up rates on the state level.

The variables FOREIGN (percentage of foreigners in the population), $\mathrm{Y}^{\mathrm{a}}$ (real Gross Domestic Product per capita in constant prices), M15-24 (percentage of males aged 15-24 in the population) and $\mathrm{Y}^{\mathrm{r}}$ (relative distance between states' GDP and federal GDP) result from our own calculations on the basis of Statistical Yearbooks from the Federal Statistical Office of Germany (Statistisches Bundesamt).

The variable UNEMPL (unemployment rate) was taken from annual reports of the Federal Employment Service (Bundesanstalt für Arbeit) and the variable UNEMPL24 (share of unemployed persons under 25 years of age out of all unemployed persons) is our own calculation on the basis of the periodical "Strukturanalyse" of the same office. Since the number of unemployed persons under 25 years of age is not available prior to 1991 at the state level the variable UNEMPL24 can only be used for estimations based on the short panel. Since we run exclusively fixed-effects regressions in the long panel and because the latter consist only of West German states, the variables EAST (indicator variable for East Germany) and CITY (indicator variable for the city-states) can only be used in the short panel.

${ }^{10}$ This can be justified by the fact that former West-Berlin is about $65 \%$ larger in population size and $150 \%$ larger in GDP than East-Berlin. Because of the fast adjustment of East Berlin's living conditions to West German standards the united city may be more appropriately considered West German than East German. 
Other variables are exclusively used in the long panel. The use of $\mathrm{Y}^{\mathrm{r}}$ in the short panel (1993-1996) is not reasonable since the relative income measure does not exhibit enough variation over time.

Table 3: List of variables used in regression analysis

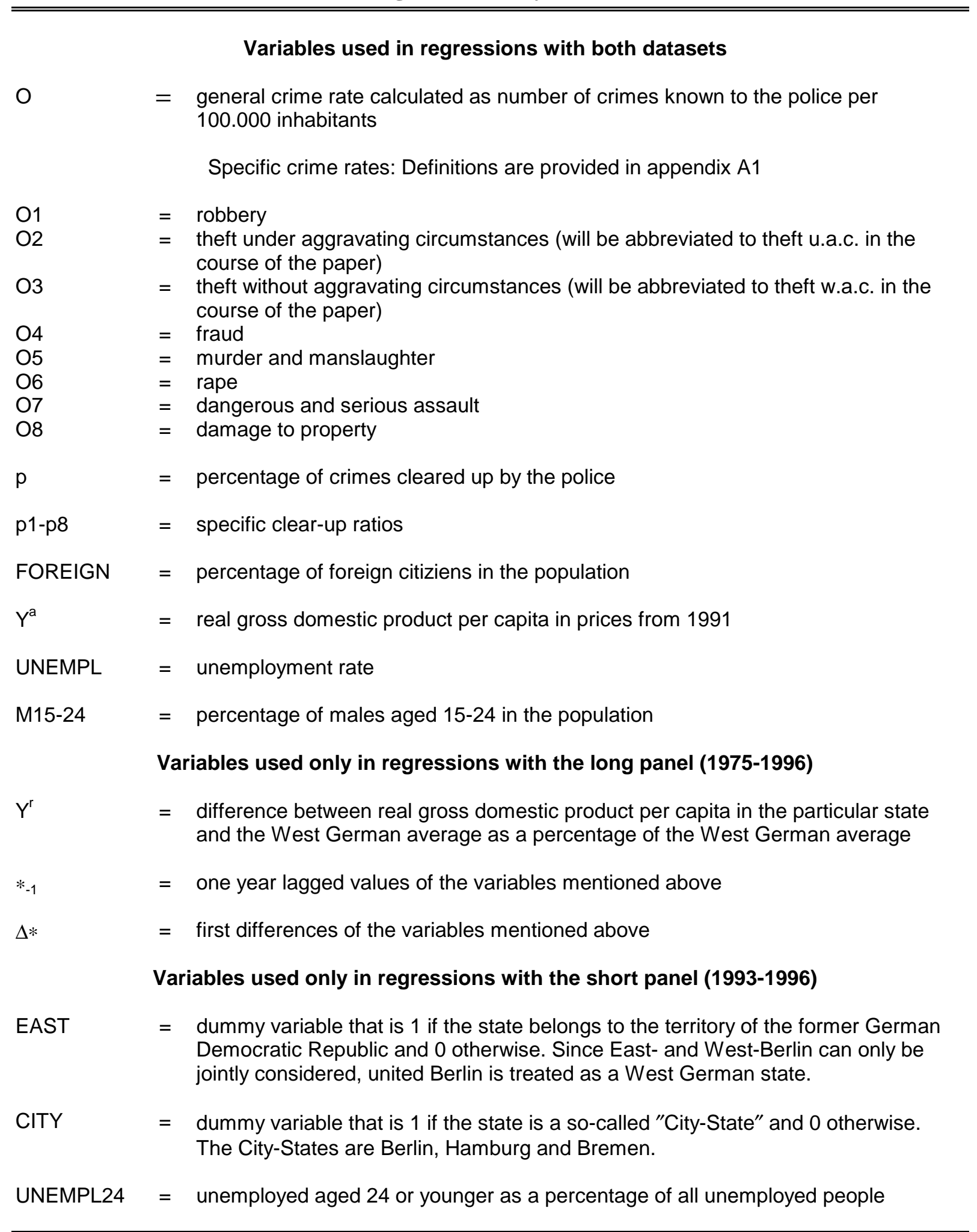




\section{Results}

Our results are based on static and dynamic ECM panel data modelling. Table 4 presents static fixed-effect estimations for annual data of the West German states, 1975-1996. Table 5 reveals the corresponding ECM specification, whereas Table 6 shows results for united Germany, 1993-1996. The relatively short period of the last sample is the result of unreliable crime data for East Germany before 1993. According to notes given in our data source (BKA, Polizeistatistik 1996), East German police statistics of the years 1990 to 1992 are biased due to administrative adjustment problems during the first years after German unification (and data from the former German Democratic Republic are not comparable with West German data before 1990). We first comment on results presented in Table 4 and 5. After this, we check whether the results hold for recent data of unified Germany.

As in most empirical studies investigating aggregate crime, the effect of the deterrence variable $p$ has the correct negative sign. The aggregate parameter is -0.20 in the static framework and -0.28 in the ECM model. ${ }^{11}$ It is somewhat smaller than the median elasiticity of about -0.5 that is given in Eide (1997), who summarizes the estimates of 21 international cross section studies based on a variety of model specifications, types of data and regression techniques. The deterrence hypothesis works quite well for crime against property, in particular theft u.a.c. and robbery. A wrong sign, however, is found for fraud, though the parameter becomes insignificant in Table 5, where ECM-dynamics are taken into account. ${ }^{12}$

The demographic factors reveal important and significant influences. Relatively large young cohorts (we measure the relative size of the group 15 to 24 years old) increase crime rates in the majority of crime categories. Looking at the size of the parameter, we find, perhaps not surprisingly, that theft u.a.c. reacts mainly to the number of young people (elasticities in Tables 4 and 5, resp.: 1.0, 1.2). Urbanization effects are covered by fixed effects (i.e. the effect of states which are highly significant in all specifications). We first started by directly considering population density. It was highly significant with expected higher crime rates in densely populated areas. Then we added fixed effects. They remained significant, but population density became insignificant. We conclude that fixed effects cover population density but that they contain unobserved heterogeneity not measured by population density alone. Thus, we stay with fixed effects only. The positive impact of foreigners on crime rates is significant at a first glance (see Table 4). However, significance levels may be biased due to serial correlation, as is suggested by the

${ }^{11}$ In order to investigate potential biases due to the simultaneity between crime and clear-up rates, we have run regressions with delayed clear-up ratios. As can be seen by the comparison of Table 4 and Table A2.1, estimated coefficients do not differ significantly.

${ }^{12}$ Positive sign in the supply of offenses function would indicate risk-loving criminals, inferiority of leisure or the endowment income effect of the Slutsky-equation (known from the reasoning behind the backward-bending labour-supply curve) (see Entorf, 1998 for details). 
low BFN-DW-statistic ${ }^{13}$ for panel data in Table 4. In Table 5, we observe that among the various types of crime only theft u.a.c. and w.a.c. remain significant. In particular, there is no significant difference to Germans with respect to crime against the person. Thus, since theft is the category closest to the rational offender, one might conclude that foreigners commit crime for economic reasons. Of course, such conclusions can only be preliminary and would need more (micro) studies that can control for individual effects such as neighbourhood and social interaction.

Absolute income, measured by GDP p.c., is used as an indicator of illegal income opportunities. In the sense of Ehrlich (1973), it is an indicator for the value of wealth within the area of potential criminal activies (here: within states). The higher potential gains are, the higher are the crime rates. In fact, for all types of crime except "rape" and "murder" the absolute income variable has positive signs. The positive effect for murder can also be found in the analysis of international data (see Brantingham and Easton, 1996, Entorf, 1996). Somewhat surprising is the positive sign of assault. The lower income is compared to average income, the lower are potential legal income opportunities within the neighbourhood area (Ehrlich, 1973). For the rational offender, low legal income opportunities increase the probability of committing a crime. In fact, most of the estimates confirm the theoretically expected negative sign for relative income (exceptions rape, murder), though the ECM framework reveals insignificance in 5 out of 8 categories. (Since one might suspect that the opposite signs of both income variables are the result of collinearity, we have omitted relative income in Tables A2.2, A2.4 and absolute income in Tables A2.3 and A2.5. Results reveal robust signs of both income variables. Of course, there will be different parameters because of the omitted variable bias).

Unemployment, finally, shows small, often insignificant and ambiguous signs. In the ECM framework, only theft w.a.c., fraud and rape are significant, but the signs (negative for rape and theft) are hard to explain in a conventional framework. There are, however, explanations given by criminologists (Sutherland and Cressey, 1974) predicting that employment increases delinquent behaviour by exposing individuals to a wider network of peers (see Ploeger, 1997, for empirical evidence).

Completing our conclusions based on Table 5, we observe significant and correctly signed ECM parameters (i.e. the parameter $g$ in eq. 3). They range between -0.25 (assault) and -0.68 (aggregate category), indicating a relatively quick convergence to equilibrium. Differenced variables representing short-run corrections of disequilibrium situations mostly reveal no significant differences when compared to the long-run equilibrium behaviour. An exception is the lack of significance of absolute and relative income variables. Evidently, the potential offenders' perception of legal and illegal income opportunities does not change with temporary

${ }^{13}$ Bhargava, Franzini, Narendranathan (1982) simulate and tabulate critical values for different N, $\mathrm{T}$ and numbers of regressors. 
income fluctuations. Only permanent income changes determine the (long-run) development of crime.

Table 6 reveals that the impact of unemployment is higher and positive throughout in recent unified Germany. Moreover, economic reasons become clearer than in the previous sample. The "economic" categories robbery and theft u.a.c. have high elasticities about one or above. (We only run static regressions, so corresponding tvalues could be misleading. However, since we only have 4 years of observations, and only small variation in some of the variables, ECM modelling would not make sense).

Table 6 distinguishes between being "young" and being "young and unemployed".There is no clear result indicating that it is exclusively the fact of being "young and unemployed" that leads to crime. Even after controlling for the possibility of being in the group of young unemployed, simply being young is more often associated with theft u.a.c. and w.a.c., rape and assault than being in other age groups. Nevertheless, there are clear signs that being young and unemployed increases the probability of committing a crime. In all categories this variable has positive effects and in 5 out of 8 categories the t-value is above 1.94 .

With respect to the probability of being detected, the deterrence parameter seems to be higher than in Tables 4 and 5 (theft u.a.c.: -0.60 , theft w.a.c.:-0.91, robbery: even -1.20). With the exception of the surprisingly high estimate for murder (-1.94), the estimates confirm the better performance of the deterrence hypothesis for crime against property.

Income is only measured in terms of absolute income. In the short panel, there is not enough variation among relative income and absolute income to allow for both types of income. The missing variable might be the reason for the very small and insignificant effect for the aggregate category. The positive signs for crimes against property (robbery, theft, fraud), however, are confirmed.

Crimes against property also is the "favoured" crime in East Germany, as can be seen from the dummy variable for East German states. All types of crime except assault reveal higher crime rates than for West German states. The biggest difference can be detected for robbery, where (cet. par.) East German states have more than $120 \%$ higher crime rates than West German non-city states.

The remaining variables do not reveal any surprises. CITY measures the (higher) crime premium in "city-states" (Berlin, Bremen, Hamburg). As before, FOREIGN, is associated with positive but not necessarily significant crime effects. 
Table 4: Estimates of the supply-of-offenses functions: West Germany 1975-1996

\begin{tabular}{|c|c|c|c|c|c|}
\hline $\begin{array}{l}\text { Dependent variables } \\
\text { Independent variables }\end{array}$ & $\begin{array}{c}\ln O \\
(1) \\
\text { All crimes }\end{array}$ & $\begin{array}{c}\ln \mathrm{O} 1 \\
(2) \\
\text { Robbery }\end{array}$ & $\begin{array}{c}\operatorname{lnO} 2 \\
(3) \\
\text { Theft u.a.c. }\end{array}$ & $\begin{array}{c}\ln \mathrm{O} 3 \\
(4) \\
\text { Theft w.a.c }\end{array}$ & $\begin{array}{l}\operatorname{lnO} 4 \\
(5) \\
\text { Fraud }\end{array}$ \\
\hline Constant & $\begin{array}{l}-1.93^{*} \\
(-3.74)\end{array}$ & $\begin{array}{c}-0.66 \\
(-0.46)\end{array}$ & $\begin{array}{l}1.75^{*} \\
(2.03)\end{array}$ & $\begin{array}{c}1.18 \\
(1.68)\end{array}$ & $\begin{array}{l}-12.96 \\
(-5.58)\end{array}$ \\
\hline Inp, Inp1-Inp4 & $\begin{array}{l}-0.20^{*} \\
(-3.43)\end{array}$ & $\begin{array}{l}-0.74^{*} \\
(-7.72)\end{array}$ & $\begin{array}{c}-0.43^{*} \\
(-12.43)\end{array}$ & $\begin{array}{c}-0.08 \\
(-0.77)\end{array}$ & $\begin{array}{c}1.12^{*} \\
(4.07)\end{array}$ \\
\hline InFOREIGN & $\begin{array}{l}0.35^{\star} \\
(9.80)\end{array}$ & $\begin{array}{c}0.99^{\star} \\
(10.77)\end{array}$ & $\begin{array}{l}0.42^{*} \\
(7.42)\end{array}$ & $\begin{array}{l}0.49^{*} \\
(9.53)\end{array}$ & $\begin{array}{l}0.26^{*} \\
(2.16)\end{array}$ \\
\hline $\ln Y^{a}$ & $\begin{array}{c}0.89^{*} \\
(19.56)\end{array}$ & $\begin{array}{c}0.40^{*} \\
(3.33)\end{array}$ & $\begin{array}{l}0.34^{*} \\
(4.24)\end{array}$ & $\begin{array}{l}0.41^{*} \\
(4.80)\end{array}$ & $\begin{array}{l}1.23^{*} \\
(7.91)\end{array}$ \\
\hline $\ln Y^{r}$ & $\begin{array}{l}-1.12^{*} \\
(-9.68)\end{array}$ & $\begin{array}{l}-0.73^{*} \\
(-2.35)\end{array}$ & $\begin{array}{l}-0.90^{*} \\
(-4.71)\end{array}$ & $\begin{array}{l}-0.39^{*} \\
(-2.12)\end{array}$ & $\begin{array}{l}-1.02^{*} \\
(-2.68)\end{array}$ \\
\hline InUNEMPL & $\begin{array}{l}0.04^{*} \\
(2.95)\end{array}$ & $\begin{array}{c}0.01 \\
(0.25)\end{array}$ & $\begin{array}{l}0.08^{*} \\
(3.51)\end{array}$ & $\begin{array}{l}-0.14^{*} \\
(-5.43)\end{array}$ & $\begin{array}{l}0.37^{*} \\
(7.62)\end{array}$ \\
\hline InM15-24 & $\begin{array}{c}0.54^{*} \\
(14.38)\end{array}$ & $\begin{array}{c}0.38^{*} \\
(4.12)\end{array}$ & $\begin{array}{c}1.01^{*} \\
(17.08)\end{array}$ & $\begin{array}{c}0.66^{\star} \\
(12.41)\end{array}$ & $\begin{array}{c}-0.05 \\
(-0.37)\end{array}$ \\
\hline Baden-Württemberg & $\begin{array}{l}-0.07^{*} \\
(-2.77)\end{array}$ & $\begin{array}{l}-0.16^{*} \\
(-2.78)\end{array}$ & $\begin{array}{l}0.11^{*} \\
(2.84)\end{array}$ & $\begin{array}{l}-0.18^{*} \\
(-5.51)\end{array}$ & $\begin{array}{c}0.17^{*} \\
(2.26)\end{array}$ \\
\hline Berlin & $\begin{array}{c}0.88^{*} \\
(27.25)\end{array}$ & $\begin{array}{c}1.02^{*} \\
(13.31)\end{array}$ & $\begin{array}{c}1.25^{\star} \\
(26.61)\end{array}$ & $\begin{array}{c}0.77^{\star} \\
(18.72)\end{array}$ & $\begin{array}{l}0.53^{*} \\
(5.64)\end{array}$ \\
\hline Bremen & $\begin{array}{c}0.90^{*} \\
(22.12)\end{array}$ & $\begin{array}{c}1.30^{*} \\
(15.81)\end{array}$ & $\begin{array}{c}1.46^{*} \\
(27.17)\end{array}$ & $\begin{array}{c}0.88^{*} \\
(19.97)\end{array}$ & $\begin{array}{c}0.56^{*} \\
(5.49)\end{array}$ \\
\hline Hamburg & $\begin{array}{c}0.93^{*} \\
(16.90)\end{array}$ & $\begin{array}{l}1.31^{*} \\
(9.77)\end{array}$ & $\begin{array}{c}1.48^{*} \\
(18.63)\end{array}$ & $\begin{array}{c}0.81^{*} \\
(11.64)\end{array}$ & $\begin{array}{l}0.93^{*} \\
(5.90)\end{array}$ \\
\hline Hesse & $\begin{array}{l}0.23^{*} \\
(7.62)\end{array}$ & $\begin{array}{l}0.25^{\star} \\
(3.95)\end{array}$ & $\begin{array}{c}0.70^{*} \\
(18.74)\end{array}$ & $\begin{array}{l}0.10^{*} \\
(2.81)\end{array}$ & $\begin{array}{l}0.22^{*} \\
(3.02)\end{array}$ \\
\hline Lower Saxony & $\begin{array}{c}0.40^{*} \\
(11.81)\end{array}$ & $\begin{array}{c}0.86^{*} \\
(11.52)\end{array}$ & $\begin{array}{c}0.89^{\star} \\
(19.14)\end{array}$ & $\begin{array}{c}0.57^{\star} \\
(12.11)\end{array}$ & $\begin{array}{c}0.15 \\
(1.46)\end{array}$ \\
\hline North Rhine-Westphalia & $\begin{array}{l}0.20^{*} \\
(8.33)\end{array}$ & $\begin{array}{l}0.33^{*} \\
(7.78)\end{array}$ & $\begin{array}{c}0.76^{*} \\
(29.46)\end{array}$ & $\begin{array}{l}0.19^{*} \\
(7.24)\end{array}$ & $\begin{array}{c}0.02 \\
(0.39)\end{array}$ \\
\hline Rhineland-Palatinate & $\begin{array}{l}0.14^{\star} \\
(5.74)\end{array}$ & $\begin{array}{l}0.42^{*} \\
(7.01)\end{array}$ & $\begin{array}{c}0.46^{*} \\
(12.47)\end{array}$ & $\begin{array}{l}0.25^{\star} \\
(6.11)\end{array}$ & $\begin{array}{l}0.19^{*} \\
(2.41)\end{array}$ \\
\hline Saarland & $\begin{array}{l}0.16^{\star} \\
(5.44)\end{array}$ & $\begin{array}{l}0.65^{\star} \\
(9.63)\end{array}$ & $\begin{array}{l}0.39^{*} \\
(9.43)\end{array}$ & $\begin{array}{c}0.46^{*} \\
(10.23)\end{array}$ & $\begin{array}{l}-0.28^{*} \\
(-3.05)\end{array}$ \\
\hline Schleswig-Holstein & $\begin{array}{c}0.66^{*} \\
(17.14)\end{array}$ & $\begin{array}{c}1.02^{*} \\
(11.94)\end{array}$ & $\begin{array}{c}1.10^{*} \\
(20.84)\end{array}$ & $\begin{array}{c}0.89^{\star} \\
(15.76)\end{array}$ & $\begin{array}{l}0.27^{\star} \\
(2.29)\end{array}$ \\
\hline Adjusted R-squared & 0.986 & 0.965 & 0.982 & 0.959 & 0.903 \\
\hline Sum of squared residuals & 0.049 & 0.123 & 0.076 & 0.070 & 0.158 \\
\hline BFN-DW-statistic & 1.12 & 0.82 & 1.04 & 0.76 & 0.83 \\
\hline Wald test on fixed effects & 3117.26 & 847.26 & 3201.38 & 1887.29 & 266.39 \\
\hline
\end{tabular}


Table 4: continued

\begin{tabular}{|c|c|c|c|c|c|}
\hline $\begin{array}{l}\text { Dependent variables } \\
\text { Independent variables }\end{array}$ & $\begin{array}{c}\ln O \\
(6) \\
\text { All crimes }\end{array}$ & $\begin{array}{l}\text { InO5 } \\
(7) \\
\text { Murder }\end{array}$ & $\begin{array}{l}\operatorname{lnO6} \\
(8) \\
\text { Rape }\end{array}$ & $\begin{array}{c}\operatorname{lnO7} \\
(9) \\
\text { Assault } \\
\end{array}$ & $\begin{array}{c}\mathrm{InO} 8 \\
(10) \\
\text { Vandalism }\end{array}$ \\
\hline Constant & $\begin{array}{l}-1.93^{*} \\
(-3.74)\end{array}$ & $\begin{array}{c}9.87^{*} \\
(4.37)\end{array}$ & $\begin{array}{l}11.75^{*} \\
(8.86)\end{array}$ & $\begin{array}{c}-8.72^{*} \\
(-4.92)\end{array}$ & $\begin{array}{l}-3.41^{*} \\
(-2.22)\end{array}$ \\
\hline Inp, Inp5-Inp8 & $\begin{array}{l}-0.20^{*} \\
(-3.43)\end{array}$ & $\begin{array}{l}-0.64^{*} \\
(-1.99)\end{array}$ & $\begin{array}{l}-0.41^{*} \\
(-3.43)\end{array}$ & $\begin{array}{l}0.86^{\star} \\
(3.28)\end{array}$ & $\begin{array}{l}-0.27^{*} \\
(-3.36)\end{array}$ \\
\hline InFOREIGN & $\begin{array}{l}0.35^{\star} \\
(9.80)\end{array}$ & $\begin{array}{c}0.23 \\
(1.90)\end{array}$ & $\begin{array}{c}0.42^{*} \\
(4.86)\end{array}$ & $\begin{array}{l}0.44^{*} \\
(5.37)\end{array}$ & $\begin{array}{l}0.20^{*} \\
(2.55)\end{array}$ \\
\hline $\ln Y^{a}$ & $\begin{array}{c}0.89^{*} \\
(19.56)\end{array}$ & $\begin{array}{l}-0.64^{*} \\
(-4.25)\end{array}$ & $\begin{array}{l}-0.95^{*} \\
(-8.61)\end{array}$ & $\begin{array}{l}0.74^{*} \\
(7.57)\end{array}$ & $\begin{array}{l}0.88^{*} \\
(6.78)\end{array}$ \\
\hline $\ln Y^{r}$ & $\begin{array}{l}-1.12^{*} \\
(-9.68)\end{array}$ & $\begin{array}{c}0.08 \\
(0.22)\end{array}$ & $\begin{array}{c}0.42 \\
(1.48)\end{array}$ & $\begin{array}{l}-1.23^{*} \\
(-4.78)\end{array}$ & $\begin{array}{l}-1.19^{*} \\
(-4.62)\end{array}$ \\
\hline InUNEMPL & $\begin{array}{l}0.04^{*} \\
(2.95)\end{array}$ & $\begin{array}{c}0.08 \\
(1.60)\end{array}$ & $\begin{array}{l}-0.18^{*} \\
(-5.00)\end{array}$ & $\begin{array}{c}-0.05 \\
(-1.52)\end{array}$ & $\begin{array}{c}0.00 \\
(-0.04)\end{array}$ \\
\hline InM15-24 & $\begin{array}{c}0.54^{*} \\
(14.38)\end{array}$ & $\begin{array}{c}0.25^{\star} \\
(2.06)\end{array}$ & $\begin{array}{l}0.72^{*} \\
(7.98)\end{array}$ & $\begin{array}{l}0.38^{*} \\
(4.74)\end{array}$ & $\begin{array}{l}0.39^{*} \\
(3.99)\end{array}$ \\
\hline Baden-Württemberg & $\begin{array}{l}-0.07^{*} \\
(-2.77)\end{array}$ & $\begin{array}{c}0.08 \\
(1.00)\end{array}$ & $\begin{array}{c}-0.05 \\
(-0.91)\end{array}$ & $\begin{array}{l}-0.20^{*} \\
(-3.98)\end{array}$ & $\begin{array}{l}-0.10^{*} \\
(-2.00)\end{array}$ \\
\hline Berlin & $\begin{array}{c}0.88^{*} \\
(27.25)\end{array}$ & $\begin{array}{c}0.53^{*} \\
(5.64)\end{array}$ & $\begin{array}{c}0.91^{*} \\
(11.74)\end{array}$ & $\begin{array}{c}1.32^{*} \\
(17.64)\end{array}$ & $\begin{array}{c}0.87^{*} \\
(14.58)\end{array}$ \\
\hline Bremen & $\begin{array}{c}0.90^{*} \\
(22.12)\end{array}$ & $\begin{array}{l}0.90^{*} \\
(8.84)\end{array}$ & $\begin{array}{c}1.20^{*} \\
(15.07)\end{array}$ & $\begin{array}{c}1.09^{\star} \\
(13.73)\end{array}$ & $\begin{array}{c}0.74^{*} \\
(11.92)\end{array}$ \\
\hline Hamburg* & $\begin{array}{c}0.93^{*} \\
(16.90)\end{array}$ & $\begin{array}{l}0.46^{\star} \\
(2.89)\end{array}$ & $\begin{array}{l}1.16^{\star} \\
(9.75)\end{array}$ & $\begin{array}{l}0.74^{*} \\
(6.55)\end{array}$ & $\begin{array}{l}0.73^{*} \\
(7.65)\end{array}$ \\
\hline Hesse & $\begin{array}{c}0.23^{*} \\
(7.62)\end{array}$ & $\begin{array}{c}0.34^{*} \\
(4.62)\end{array}$ & $\begin{array}{c}0.19^{\star} \\
(3.25)\end{array}$ & $\begin{array}{c}-0.01 \\
(-0.25)\end{array}$ & $\begin{array}{c}0.20^{*} \\
(4.04)\end{array}$ \\
\hline Lower Saxony & $\begin{array}{c}0.40^{*} \\
(11.81)\end{array}$ & $\begin{array}{c}0.19 \\
(1.90)\end{array}$ & $\begin{array}{l}0.44^{*} \\
(6.12)\end{array}$ & $\begin{array}{l}0.27^{\star} \\
(4.27)\end{array}$ & $\begin{array}{c}0.32^{*} \\
(5.28)\end{array}$ \\
\hline North Rhine-Westphalia & $\begin{array}{l}0.20^{*} \\
(8.33)\end{array}$ & $\begin{array}{l}-0.14^{*} \\
(-2.60)\end{array}$ & $\begin{array}{l}0.11^{*} \\
(2.82)\end{array}$ & $\begin{array}{l}0.23^{\star} \\
(6.36)\end{array}$ & $\begin{array}{l}0.14^{*} \\
(3.95)\end{array}$ \\
\hline Rhineland-Palatinate & $\begin{array}{l}0.14^{\star} \\
(5.74)\end{array}$ & $\begin{array}{c}0.29^{\star} \\
(3.66)\end{array}$ & $\begin{array}{l}0.21^{*} \\
(3.72)\end{array}$ & $\begin{array}{c}0.08 \\
(1.55)\end{array}$ & $\begin{array}{c}0.06 \\
(1.17)\end{array}$ \\
\hline Saarland & $\begin{array}{l}0.16^{\star} \\
(5.44)\end{array}$ & $\begin{array}{c}0.26^{*} \\
(2.93)\end{array}$ & $\begin{array}{l}0.18^{*} \\
(2.74)\end{array}$ & $\begin{array}{l}0.36^{*} \\
(6.32)\end{array}$ & $\begin{array}{l}0.23^{*} \\
(4.07)\end{array}$ \\
\hline Schleswig-Holstein & $\begin{array}{c}0.66^{*} \\
(17.14)\end{array}$ & $\begin{array}{c}-0.05 \\
(-0.41)\end{array}$ & $\begin{array}{l}0.50^{*} \\
(6.14)\end{array}$ & $\begin{array}{l}0.53^{*} \\
(6.85)\end{array}$ & $\begin{array}{c}0.71^{*} \\
(10.29)\end{array}$ \\
\hline Adjusted R-squared & 0.986 & 0.732 & 0.921 & 0.933 & 0.925 \\
\hline Sum of squared residuals & 0.049 & 0.161 & 0.112 & 0.103 & 0.090 \\
\hline BFN-DW-statistic & 1.12 & 1.06 & 1.04 & 0.49 & 0.65 \\
\hline Wald test on fixed effects & 3117.26 & 362.33 & 558.46 & 972.79 & 940.40 \\
\hline
\end{tabular}

Note: Nobs. is 235, 202 for vandalism. "Bavaria" represents the reference state dummy variable. 
Table 5: ECM-estimates of the supply-of-offenses functions: West Germany 1975-1996

\begin{tabular}{|c|c|c|c|c|c|}
\hline $\begin{array}{l}\text { Dependent variables } \\
\text { Independent variables }\end{array}$ & $\begin{array}{c}\ln O \\
(1) \\
\text { All crimes } \\
\end{array}$ & $\begin{array}{c}\ln \mathrm{O} 1 \\
(2) \\
\text { Robbery }\end{array}$ & $\begin{array}{c}\ln \mathrm{O} 2 \\
(3) \\
\text { Theft u.a.c. }\end{array}$ & $\begin{array}{c}\operatorname{lnO3} \\
(4) \\
\text { Theft w.a.c }\end{array}$ & $\begin{array}{l}\operatorname{lnO} 4 \\
(5) \\
\text { Fraud }\end{array}$ \\
\hline $\mathrm{InO}_{-1}, \mathrm{InO} 1_{-1}-\operatorname{lnO} 4_{-1}$ & $\begin{array}{c}-0.68^{*} \\
(-11.56)\end{array}$ & $\begin{array}{c}-0.34^{*} \\
(-6.30)\end{array}$ & $\begin{array}{l}-0.54^{*} \\
(-9.19)\end{array}$ & $\begin{array}{l}-0.47^{*} \\
(-8.82)\end{array}$ & $\begin{array}{l}-0.45^{\star} \\
(-7.82)\end{array}$ \\
\hline Constant & $\begin{array}{l}-1.49 \\
(-1.57)\end{array}$ & $\begin{array}{c}-11.65^{\star} \\
(-2.50)\end{array}$ & $\begin{array}{c}2.03 \\
(1.04)\end{array}$ & $\begin{array}{c}2.62 \\
(1.49)\end{array}$ & $\begin{array}{r}-12.29^{*} \\
(-2.00)\end{array}$ \\
\hline $\operatorname{Inp}{ }_{-1}, \operatorname{Inp} 1_{-1}-\operatorname{Inp} 4_{-1}$ & $\begin{array}{c}-0.28^{*} \\
(-3.67)\end{array}$ & $\begin{array}{c}-1.52^{*} \\
(-5.94)\end{array}$ & $\begin{array}{c}-0.42^{*} \\
(-7.32)\end{array}$ & $\begin{array}{c}-0.08 \\
(-0.40)\end{array}$ & $\begin{array}{c}0.95 \\
(1.54)\end{array}$ \\
\hline InFOREIGN -1 & $\begin{array}{l}0.21^{*} \\
(3.82)\end{array}$ & $\begin{array}{c}0.35 \\
(1.39)\end{array}$ & $\begin{array}{l}0.32^{*} \\
(3.01)\end{array}$ & $\begin{array}{l}0.28^{*} \\
(2.89)\end{array}$ & $\begin{array}{c}0.27 \\
(0.96)\end{array}$ \\
\hline $\ln Y_{-1}^{a}$ & $\begin{array}{c}0.93^{*} \\
(10.09)\end{array}$ & $\begin{array}{c}1.93^{\star} \\
(4.08)\end{array}$ & $\begin{array}{c}0.30 \\
(1.59)\end{array}$ & $\begin{array}{l}0.38^{*} \\
(2.09)\end{array}$ & $\begin{array}{l}1.26^{*} \\
(2.65)\end{array}$ \\
\hline $\ln Y_{-1}^{r}$ & $\begin{array}{l}-1.24^{*} \\
(-7.77)\end{array}$ & $\begin{array}{l}-2.59^{\star} \\
(-3.27)\end{array}$ & $\begin{array}{l}-1.15^{*} \\
(-3.50)\end{array}$ & $\begin{array}{l}-0.50 \\
(-1.58)\end{array}$ & $\begin{array}{l}-1.22 \\
(-1.50)\end{array}$ \\
\hline InUNEMPL $_{-1}$ & $\begin{array}{c}0.05 \\
(1.81)\end{array}$ & $\begin{array}{c}-0.08 \\
(-0.67)\end{array}$ & $\begin{array}{c}0.00 \\
(-0.02)\end{array}$ & $\begin{array}{l}-0.13^{*} \\
(-2.57)\end{array}$ & $\begin{array}{l}0.25^{*} \\
(2.06)\end{array}$ \\
\hline InM15-24-1 & $\begin{array}{l}0.43^{*} \\
(7.85)\end{array}$ & $\begin{array}{c}0.16 \\
(0.66)\end{array}$ & $\begin{array}{c}1.20^{*} \\
(10.64)\end{array}$ & $\begin{array}{l}0.31^{*} \\
(2.99)\end{array}$ & $\begin{array}{l}-0.06 \\
(-0.20)\end{array}$ \\
\hline Baden-Württemberg & $\begin{array}{c}-0.01 \\
(-0.20)\end{array}$ & $\begin{array}{c}0.02 \\
(0.17)\end{array}$ & $\begin{array}{c}0.15^{\star} \\
(2.22)\end{array}$ & $\begin{array}{c}-0.08 \\
(-1.34)\end{array}$ & $\begin{array}{c}0.14 \\
(0.81)\end{array}$ \\
\hline Berlin & $\begin{array}{c}0.94^{*} \\
(21.57)\end{array}$ & $\begin{array}{l}1.23^{\star} \\
(6.55)\end{array}$ & $\begin{array}{c}1.39^{\star} \\
(17.00)\end{array}$ & $\begin{array}{c}0.85^{*} \\
(11.80)\end{array}$ & $\begin{array}{l}0.66^{*} \\
(3.32)\end{array}$ \\
\hline Bremen & $\begin{array}{c}0.90^{*} \\
(16.41)\end{array}$ & $\begin{array}{l}1.40^{\star} \\
(6.82)\end{array}$ & $\begin{array}{c}1.63^{*} \\
(17.82)\end{array}$ & $\begin{array}{c}0.91^{*} \\
(12.09)\end{array}$ & $\begin{array}{l}0.64^{*} \\
(3.05)\end{array}$ \\
\hline Hamburg & $\begin{array}{c}0.97^{*} \\
(13.42)\end{array}$ & $\begin{array}{l}1.26^{\star} \\
(3.90)\end{array}$ & $\begin{array}{c}1.73^{*} \\
(12.99)\end{array}$ & $\begin{array}{l}0.89^{*} \\
(7.74)\end{array}$ & $\begin{array}{l}1.02^{*} \\
(3.17)\end{array}$ \\
\hline Hesse & $\begin{array}{c}0.27^{*} \\
(6.74)\end{array}$ & $\begin{array}{l}0.33^{*} \\
(2.29)\end{array}$ & $\begin{array}{c}0.81^{*} \\
(12.69)\end{array}$ & $\begin{array}{l}0.18^{*} \\
(2.84)\end{array}$ & $\begin{array}{c}0.25 \\
(1.70)\end{array}$ \\
\hline Lower Saxony & $\begin{array}{l}0.31^{*} \\
(6.60)\end{array}$ & $\begin{array}{l}0.50^{\star} \\
(2.73)\end{array}$ & $\begin{array}{c}0.85^{\star} \\
(10.52)\end{array}$ & $\begin{array}{l}0.44^{*} \\
(5.41)\end{array}$ & $\begin{array}{c}0.21 \\
(0.97)\end{array}$ \\
\hline North Rhine-Westphalia & $\begin{array}{l}0.21^{*} \\
(6.76)\end{array}$ & $\begin{array}{l}0.44^{*} \\
(4.58)\end{array}$ & $\begin{array}{c}0.83^{*} \\
(19.49)\end{array}$ & $\begin{array}{l}0.23^{\star} \\
(4.97)\end{array}$ & $\begin{array}{c}0.10 \\
(0.93)\end{array}$ \\
\hline Rhineland-Palatinate & $\begin{array}{l}0.09^{*} \\
(2.65)\end{array}$ & $\begin{array}{c}0.17 \\
(1.23)\end{array}$ & $\begin{array}{l}0.42^{*} \\
(6.90)\end{array}$ & $\begin{array}{l}0.16^{*} \\
(2.31)\end{array}$ & $\begin{array}{c}0.24 \\
(1.47)\end{array}$ \\
\hline Saarland & $\begin{array}{l}0.09^{*} \\
(2.22)\end{array}$ & $\begin{array}{l}0.39^{\star} \\
(2.45)\end{array}$ & $\begin{array}{l}0.37^{\star} \\
(5.04)\end{array}$ & $\begin{array}{l}0.37^{*} \\
(4.67)\end{array}$ & $\begin{array}{c}-0.23 \\
(-1.17)\end{array}$ \\
\hline Schleswig-Holstein & $\begin{array}{l}0.54^{*} \\
(9.90)\end{array}$ & $\begin{array}{l}0.48^{\star} \\
(2.20)\end{array}$ & $\begin{array}{c}1.04^{*} \\
(11.11)\end{array}$ & $\begin{array}{l}0.72^{*} \\
(7.17)\end{array}$ & $\begin{array}{c}0.31 \\
(1.15)\end{array}$ \\
\hline$\Delta p, \Delta p 1-\Delta p 4$ & $\begin{array}{c}-0.12 \\
(-1.81)\end{array}$ & $\begin{array}{l}-0.22^{*} \\
(-2.19)\end{array}$ & $\begin{array}{l}-0.16^{*} \\
(-3.58)\end{array}$ & $\begin{array}{c}0.16 \\
(1.78)\end{array}$ & $\begin{array}{c}0.63^{*} \\
(2.37)\end{array}$ \\
\hline$\triangle$ FOREIGN & $\begin{array}{l}0.18^{*} \\
(2.41)\end{array}$ & $\begin{array}{c}0.11 \\
(0.63)\end{array}$ & $\begin{array}{l}0.38^{*} \\
(3.22)\end{array}$ & $\begin{array}{l}0.23^{*} \\
(2.35)\end{array}$ & $\begin{array}{l}-0.21 \\
(-0.84)\end{array}$ \\
\hline$\Delta \mathrm{Y}^{\mathrm{a}}$ & $\begin{array}{c}-0.09 \\
(-0.67)\end{array}$ & $\begin{array}{c}0.23 \\
(0.76)\end{array}$ & $\begin{array}{c}-0.35 \\
(-1.59)\end{array}$ & $\begin{array}{c}-0.28 \\
(-1.56)\end{array}$ & $\begin{array}{c}0.08 \\
(0.17)\end{array}$ \\
\hline$\Delta Y^{r}$ & $\begin{array}{c}0.00 \\
(0.56)\end{array}$ & $\begin{array}{c}0.00 \\
(-0.23)\end{array}$ & $\begin{array}{c}0.00 \\
(0.41)\end{array}$ & $\begin{array}{c}0.00 \\
(0.20)\end{array}$ & $\begin{array}{c}-0.02 \\
(-0.72)\end{array}$ \\
\hline$\triangle U N E M P L$ & $\begin{array}{l}0.07^{*} \\
(2.80)\end{array}$ & $\begin{array}{c}0.06 \\
(1.10)\end{array}$ & $\begin{array}{c}0.06 \\
(1.51)\end{array}$ & $\begin{array}{l}-0.08^{*} \\
(-2.48)\end{array}$ & $\begin{array}{c}0.31^{*} \\
(3.68)\end{array}$ \\
\hline$\Delta \mathrm{M} 15-24$ & $\begin{array}{l}0.53^{*} \\
(3.07)\end{array}$ & $\begin{array}{c}1.52^{*} \\
(3.64)\end{array}$ & $\begin{array}{c}0.31 \\
(1.11)\end{array}$ & $\begin{array}{l}0.68^{*} \\
(2.76)\end{array}$ & $\begin{array}{l}-0.07 \\
(-0.12)\end{array}$ \\
\hline Adjusted R-squared & 0.512 & 0.244 & 0.498 & 0.419 & 0.249 \\
\hline Sum of squared residuals & 0.038 & 0.083 & 0.060 & 0.049 & 0.127 \\
\hline BFN-DW-statistic & 1.89 & 1.93 & 1.78 & 1.86 & 2.13 \\
\hline Wald test on fixed effects & 1818.87 & 135.10 & 1244.77 & 593.62 & 83.16 \\
\hline
\end{tabular}


Table 5: continued

\begin{tabular}{|c|c|c|c|c|c|}
\hline $\begin{array}{l}\text { Dependent variables } \\
\text { Independent variables }\end{array}$ & $\begin{array}{c}\ln O \\
(6) \\
\text { All crimes } \\
\end{array}$ & $\begin{array}{l}\operatorname{lnO5} \\
(7) \\
\text { Murder }\end{array}$ & $\begin{array}{l}\text { InO6 } \\
(8) \\
\text { Rape }\end{array}$ & $\begin{array}{c}\ln 07 \\
(9) \\
\text { Assault }\end{array}$ & $\begin{array}{c}\operatorname{InO} 8 \\
(10) \\
\text { Vandalism }\end{array}$ \\
\hline$\overline{\mathrm{InO}_{-1}, \operatorname{lnO} 5_{-1}-\operatorname{lnO} 8_{-1}}$ & $\begin{array}{c}-0.68^{*} \\
(-11.56)\end{array}$ & $\begin{array}{c}-0.54^{*} \\
(-8.42)\end{array}$ & $\begin{array}{l}-0.51^{*} \\
(-7.78)\end{array}$ & $\begin{array}{c}-0.25^{*} \\
(-5.87)\end{array}$ & $\begin{array}{c}-0.27^{*} \\
(-4.68)\end{array}$ \\
\hline Constant & $\begin{array}{c}-1.49 \\
(-1.57)\end{array}$ & $\begin{array}{c}1.60 \\
(0.27)\end{array}$ & $\begin{array}{l}9.71^{*} \\
(2.74)\end{array}$ & $\begin{array}{c}-16.50^{*} \\
(-3.27)\end{array}$ & $\begin{array}{c}5.34 \\
(0.66)\end{array}$ \\
\hline $\operatorname{Inp} p_{-1}, \operatorname{Inp} 5_{-1}-\operatorname{Inp} 8_{-1}$ & $\begin{array}{l}-0.28^{*} \\
(-3.67)\end{array}$ & $\begin{array}{c}-0.30 \\
(-0.38)\end{array}$ & $\begin{array}{c}-0.43 \\
(-1.51)\end{array}$ & $\begin{array}{c}-0.09 \\
(-0.12)\end{array}$ & $\begin{array}{c}0.03 \\
(0.11)\end{array}$ \\
\hline InFOREIGN $_{-1}$ & $\begin{array}{l}0.21^{*} \\
(3.82)\end{array}$ & $\begin{array}{c}0.38 \\
(1.43)\end{array}$ & $\begin{array}{c}0.17 \\
(0.84)\end{array}$ & $\begin{array}{c}-0.04 \\
(-0.14)\end{array}$ & $\begin{array}{c}0.15 \\
(0.55)\end{array}$ \\
\hline $\ln Y_{-1}^{a}$ & $\begin{array}{c}0.93^{*} \\
(10.09)\end{array}$ & $\begin{array}{c}-0.08 \\
(-0.18)\end{array}$ & $\begin{array}{c}-0.64 \\
(-1.89)\end{array}$ & $\begin{array}{l}2.09^{*} \\
(4.73)\end{array}$ & $\begin{array}{c}0.06 \\
(0.08)\end{array}$ \\
\hline $\ln Y_{-1}^{r}$ & $\begin{array}{l}-1.24^{*} \\
(-7.77)\end{array}$ & $\begin{array}{c}-0.97 \\
(-1.26)\end{array}$ & $\begin{array}{c}0.23 \\
(0.38)\end{array}$ & $\begin{array}{l}-2.30^{*} \\
(-3.32)\end{array}$ & $\begin{array}{c}-0.49 \\
(-0.51)\end{array}$ \\
\hline InUNEMPL $_{-1}$ & $\begin{array}{c}0.05 \\
(1.81)\end{array}$ & $\begin{array}{c}-0.07 \\
(-0.56)\end{array}$ & $\begin{array}{l}-0.18^{*} \\
(-2.01)\end{array}$ & $\begin{array}{c}-0.09 \\
(-0.89)\end{array}$ & $\begin{array}{c}0.02 \\
(0.18)\end{array}$ \\
\hline InM15-24-1 & $\begin{array}{l}0.43^{*} \\
(7.85)\end{array}$ & $\begin{array}{l}0.65^{*} \\
(2.47)\end{array}$ & $\begin{array}{l}0.42^{*} \\
(2.03)\end{array}$ & $\begin{array}{c}-0.15 \\
(-0.64)\end{array}$ & $\begin{array}{c}-0.10 \\
(-0.29)\end{array}$ \\
\hline Baden-Württemberg & $\begin{array}{c}-0.01 \\
(-0.20)\end{array}$ & $\begin{array}{c}0.00 \\
(0.02)\end{array}$ & $\begin{array}{c}0.03 \\
(0.27)\end{array}$ & $\begin{array}{c}0.00 \\
(-0.04)\end{array}$ & $\begin{array}{c}0.02 \\
(0.15)\end{array}$ \\
\hline Berlin & $\begin{array}{c}0.94^{*} \\
(21.57)\end{array}$ & $\begin{array}{l}0.60^{\star} \\
(3.34)\end{array}$ & $\begin{array}{l}0.97^{\star} \\
(6.01)\end{array}$ & $\begin{array}{l}1.31^{*} \\
(6.84)\end{array}$ & $\begin{array}{l}0.94^{\star} \\
(4.91)\end{array}$ \\
\hline Bremen & $\begin{array}{c}0.90^{*} \\
(16.41)\end{array}$ & $\begin{array}{l}1.09^{*} \\
(5.52)\end{array}$ & $\begin{array}{l}1.20^{*} \\
(7.18)\end{array}$ & $\begin{array}{l}0.90^{*} \\
(4.37)\end{array}$ & $\begin{array}{l}0.81^{*} \\
(4.26)\end{array}$ \\
\hline Hamburg & $\begin{array}{c}0.97^{*} \\
(13.42)\end{array}$ & $\begin{array}{l}0.66^{\star} \\
(2.23)\end{array}$ & $\begin{array}{c}1.15^{\star} \\
(4.82)\end{array}$ & $\begin{array}{c}0.46 \\
(1.55)\end{array}$ & $\begin{array}{c}0.87^{\star} \\
(3.09)\end{array}$ \\
\hline Hesse & $\begin{array}{l}0.27^{*} \\
(6.74)\end{array}$ & $\begin{array}{l}0.36^{*} \\
(2.71)\end{array}$ & $\begin{array}{c}0.23^{\star} \\
(2.07)\end{array}$ & $\begin{array}{c}0.04 \\
(0.33)\end{array}$ & $\begin{array}{c}0.23 \\
(1.54)\end{array}$ \\
\hline Lower Saxony & $\begin{array}{l}0.31^{*} \\
(6.60)\end{array}$ & $\begin{array}{c}0.24 \\
(1.25)\end{array}$ & $\begin{array}{l}0.33^{*} \\
(2.19)\end{array}$ & $\begin{array}{c}0.16 \\
(0.95)\end{array}$ & $\begin{array}{c}0.28 \\
(1.48)\end{array}$ \\
\hline North Rhine-Westphalia & $\begin{array}{c}0.21^{*} \\
(6.76)\end{array}$ & $\begin{array}{c}-0.13 \\
(-1.29)\end{array}$ & $\begin{array}{c}0.16^{\star} \\
(2.12)\end{array}$ & $\begin{array}{c}0.33^{\star} \\
(3.87)\end{array}$ & $\begin{array}{c}0.17 \\
(1.64)\end{array}$ \\
\hline Rhineland-Palatinate & $\begin{array}{l}0.09^{\star} \\
(2.65)\end{array}$ & $\begin{array}{c}0.30^{*} \\
(2.11)\end{array}$ & $\begin{array}{c}0.14 \\
(1.27)\end{array}$ & $\begin{array}{c}0.04 \\
(0.32)\end{array}$ & $\begin{array}{c}0.08 \\
(0.52)\end{array}$ \\
\hline Saarland & $\begin{array}{l}0.09^{*} \\
(2.22)\end{array}$ & $\begin{array}{c}0.29 \\
(1.69)\end{array}$ & $\begin{array}{c}0.08 \\
(0.58)\end{array}$ & $\begin{array}{l}0.38^{\star} \\
(2.47)\end{array}$ & $\begin{array}{c}0.20 \\
(1.13)\end{array}$ \\
\hline Schleswig-Holstein & $\begin{array}{l}0.54^{*} \\
(9.90)\end{array}$ & $\begin{array}{c}-0.01 \\
(-0.06)\end{array}$ & $\begin{array}{c}0.35^{*} \\
(1.98)\end{array}$ & $\begin{array}{c}0.22 \\
(1.01)\end{array}$ & $\begin{array}{c}0.65^{\star} \\
(2.94)\end{array}$ \\
\hline$\Delta p, \Delta p 5-\Delta p 8$ & $\begin{array}{c}-0.12 \\
(-1.81)\end{array}$ & $\begin{array}{c}-0.32 \\
(-1.07)\end{array}$ & $\begin{array}{l}-0.33^{*} \\
(-2.71)\end{array}$ & $\begin{array}{c}-0.35 \\
(-1.50)\end{array}$ & $\begin{array}{c}0.02 \\
(0.33)\end{array}$ \\
\hline$\triangle$ FOREIGN & $\begin{array}{c}0.18^{*} \\
(2.41)\end{array}$ & $\begin{array}{c}0.11 \\
(0.38)\end{array}$ & $\begin{array}{c}0.06 \\
(0.28)\end{array}$ & $\begin{array}{c}0.03 \\
(0.22)\end{array}$ & $\begin{array}{c}0.25 \\
(1.78)\end{array}$ \\
\hline$\Delta \mathrm{Y}^{\mathrm{a}}$ & $\begin{array}{c}-0.09 \\
(-0.67)\end{array}$ & $\begin{array}{c}-0.19 \\
(-0.35)\end{array}$ & $\begin{array}{c}-0.36 \\
(-0.95)\end{array}$ & $\begin{array}{c}0.16 \\
(0.77)\end{array}$ & $\begin{array}{c}-0.12 \\
(-0.47)\end{array}$ \\
\hline$\Delta Y^{r}$ & $\begin{array}{c}0.00 \\
(0.56)\end{array}$ & $\begin{array}{c}-0.01 \\
(-0.45)\end{array}$ & $\begin{array}{c}0.01 \\
(0.31)\end{array}$ & $\begin{array}{c}0.00 \\
(0.36)\end{array}$ & $\begin{array}{c}0.02 \\
(1.80)\end{array}$ \\
\hline$\triangle U N E M P L$ & $\begin{array}{c}0.07^{*} \\
(2.80)\end{array}$ & $\begin{array}{c}0.07 \\
(0.74)\end{array}$ & $\begin{array}{c}-0.02 \\
(-0.35)\end{array}$ & $\begin{array}{c}-0.04 \\
(-1.03)\end{array}$ & $\begin{array}{c}-0.09 \\
(-1.93)\end{array}$ \\
\hline$\Delta \mathrm{M} 15-24$ & $\begin{array}{c}0.53^{*} \\
(3.07)\end{array}$ & $\begin{array}{c}0.40 \\
(0.59)\end{array}$ & $\begin{array}{c}0.82 \\
(1.70)\end{array}$ & $\begin{array}{l}1.34^{*} \\
(5.07)\end{array}$ & $\begin{array}{c}0.17 \\
(0.42)\end{array}$ \\
\hline Adjusted R-squared & 0.512 & 0.238 & 0.222 & 0.300 & 0.216 \\
\hline Sum of squared residuals & 0.038 & 0.143 & 0.105 & 0.057 & 0.061 \\
\hline BFN-DW-statistic & 1.89 & 2.08 & 2.03 & 1.98 & 2.01 \\
\hline Wald test on fixed effects & 1818.87 & 130.42 & 122.92 & 172.45 & 113.49 \\
\hline
\end{tabular}

Note: Nobs. is 224, 191 for vandalism. "Bavaria" represents the reference state dummy variable. 


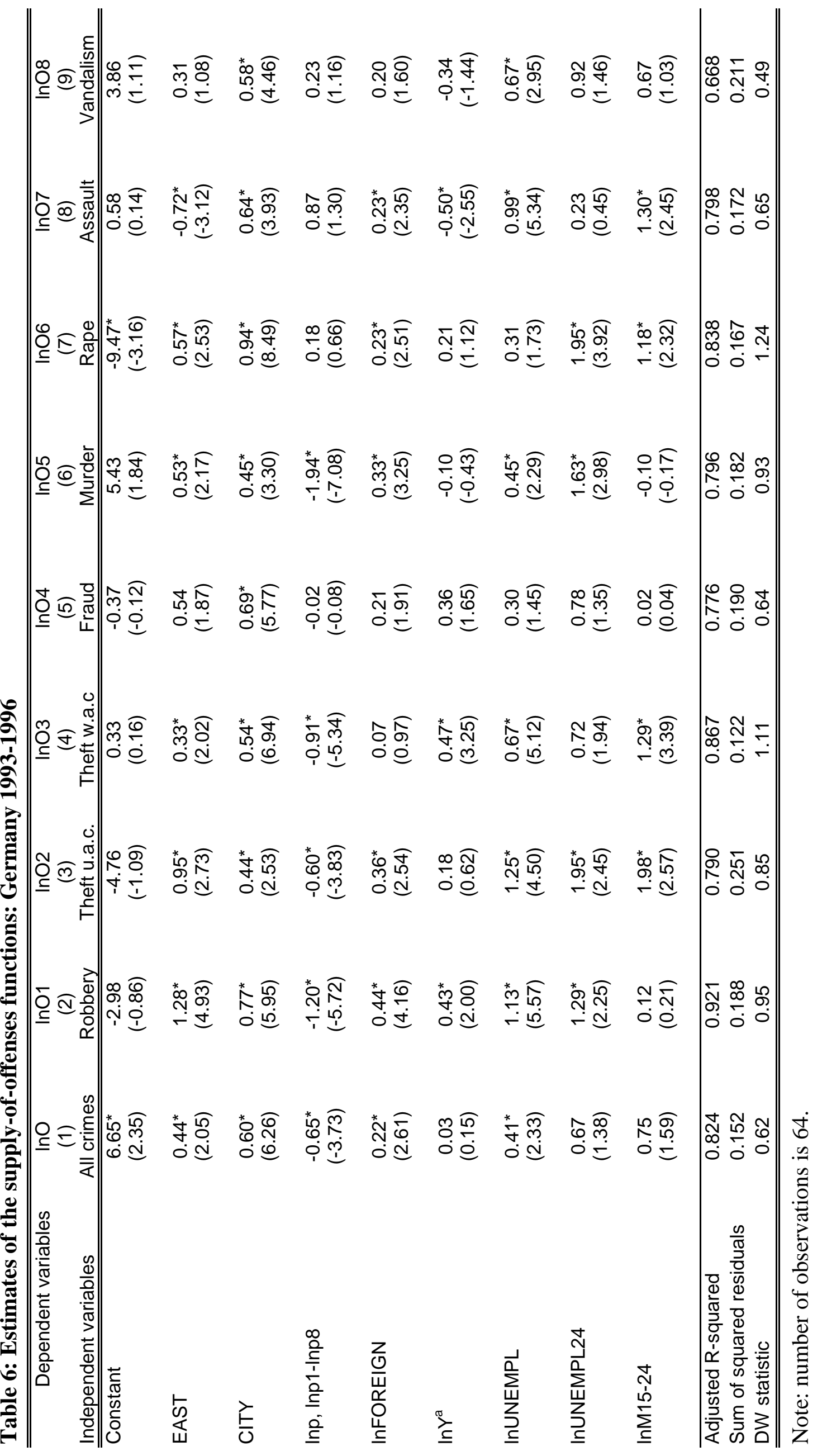




\section{Conclusions}

In this paper we estimate supply-of-offenses functions for aggregated crime and for eight different crime categories using panal data of the German Laender. We consider three groups of independent variables in our econometric/criminometric specifications: deterrence, economic and socio-demographic variables. The results confirm Becker's (1968) deterrence hypothesis for crime against property, though only weak support can be observed for crime against the person.

Economic variables that are used to measure legal and illegal income opportunities perform well in estimations for crime against property. As already suggested by Ehrlich (1973), absolute income turns out to be a measure of illegal rather than legal income opportunities (i.e. higher income is associated with higher crime rates). Results based on relative income show that a widening income gap with respect to richer regions increases the probability of delinquent behaviour. Thus, growing inequality seems to be an important factor of crime.

As regards crime in the eastern and western part of Germany, there remains a higher crime rate in the east, even after controlling for differences in legal and illegal income opportunities and other factors of crime. The reason for this is not clear. Possibly, prosecution of crime and administration of justice are still organized inefficiently in eastern Germany. An other explanation might be that the newly gained freedom has led to (temporarily?) higher violation of social norms. However, a reasonable explanation of the east-west crime differential would need further research.

Demographic factors reveal important and significant influences. As usually found in the literature, we observe higher crime rates in highly urbanized areas. Moreover, we confirm the ambigous result for general unemployment. However, being young and unemployed increases the probability of committing crimes. Additionally, also simply being young aggravates the danger of getting into the bad company of a group with harmful social interactions. Interpreting the influence of the aggregate share of foreigners is difficult in aggregate studies and can only be tentative. Our results suggest that the share of foreigners in Germany is positively associated with crime against property, in particular theft. For all other types of crime, the effect is not clear or insignificant.

Our analysis has left us with many new questions. Future research should pay more attention to social and demographic influences of crime, especially in the light of familiy background and social interactions. The practicability of this task is of course closely related to the need for less aggregated data. 


\section{Appendix}

\section{A1 Definitions of crime categories}

In this part of the appendix we present the definitions of the eight crime categories used in the estimations according to the German "Strafgesetzbuch" (StGB) i.e. penal code. If categories consist of several related offenses all relevant sections of the penal code will be presented.

\section{Murder and Manslaughter}

- Murder: ( $\$ 211$ StGB) the killing of a human being to satisfy homicidal desires, sexual instincts, greed or other low motives in ways which are malicious, cruel or dangerous to the public or to make another criminal act possible or to conceal it.

- Manslaughter: (\$212 \& 213 StGB) the killing of a human being without intention or malice; also if provoked by actions and insults of the victim.

- Assisted Suicide: (\$216 StGB; homicide on demand) the killing of a human being at the express and earnest request of that person.

\section{Rape}

- Rape: ( $\$ 177 \mathrm{StGB})$ the forcing of a woman to sexual intercourse outside of her marriage with the perpetrator or a third person through the use of or threat of a present danger to her body or life. (Sexual intercourse without valid consent.)

\section{Robbery}

- Robbery: ( $\$ 249$ StGB) the taking away of someone else's property through the use of or threat of a present danger to the body or life.

- Aggravated Robbery: ( $\$ 250$ StGB) if the perpetrator of the robbery or other participant to the robbery: carries a firearm; or, carries a weapon or other tool to overcome the resistance of another by force or the threat of force; or, brings someone in danger of death or serious bodily harm through the robbery; or, commits robbery as a member of or with a member of a gang formed for the purpose of committing theft or robbery.

- Robbery resulting in Death: ( $\$ 251 \mathrm{StGB})$ if the perpetrator of the robbery leads to the careless death of another.

- Theft with Elements of Robbery: ( $\$ 252 \mathrm{StGB})$ if a perpetrator, discovered in the act of theft, takes possession of a stolen good through the use of or threat of a present danger to the body or life of another.

- Blackmail with Elements of Robbery: ( $\$ 255 \mathrm{StGB})$ if the perpetrator blackmails a person through the use of or threat of a present danger to the body or life of another. 


\section{Dangerous and Serious Assault}

- Dangerous Assault: ( $\$ 223$ a StGB) assault using a weapon, especially a knife or other dangerous tool, or using a deceitful attack or a group or methods to endanger the life of someone.

- Serious Assault: (\$224 StGB; maiming) assault resulting in: the loss of a limb, sight in one or both eyes, hearing, speech, or the ability to procreate; or, the long term distortion of such; or, a state of sickness, paralysis, or mental illness. Includes both ( $\$ 225$ parts $1 \& 2$ StGB; "Particularly Serious Assault") negligent/unintentional and intentional bodily harm.

- Participation in a Fight: ( $\$ 227 \mathrm{StGB})$ the participation in a fight or an attack by several perpetrators which resulted in the death of a person or in serious bodily harm ( $\$ 224 \mathrm{StGB})$.

- Poisoning: ( $\$ 229$ StGB) the administration of a poison, or other substances that can destroy one's health, upon someone with the intention of damaging their health.

\section{Theft without Aggravating Circumstances (Theft w.a.c.)}

- Theft: ( $\$ 242$ StGB) the taking away of someone else's property with the intention of illegally appropriating the item.

- Home and Family Theft: ( $\$ 247 \mathrm{StGB})$ if the victims of theft or embezzlement are relatives, guardians or members of the perpetrator's household, the case is prosecuted only if a claim is filed.

- Petty Theft and Embezzlement: ( $\$ 248 \mathrm{a} \mathrm{StGB})$ if the items stolen or embezzled are of minute value, the case is pursued only if a claim is filed.

- Unauthorized Use of a Vehicle: (\$248b StGB) the use of a motor vehicle or bicycle without the consent of the authorized user / owner.

- Tapping of Electrical Power: ( $\$ 248 \mathrm{c}$ StGB) the tapping of electrical systems or installations with the intention of illegally appropriating electrical power.

\section{Theft under Aggravating Circumstances (Theft u.a.c.)}

- Aggravated Theft: ( $\$ 243$ StGB, "Particularly Serious Case of Theft") if the perpetrator of a theft: 1) breaks into, climbs into or otherwise enters a building, residence, office, business or other closed space or if the perpetrator uses a fake key or other tool to gain entry or hides in the space; or 2) steals an item which had been protected against theft by a closed container or other security measure; or 3) steals as a vocation; or 4) steals an item used in religious ceremonies or services from a church or other building or space used for religious purposes; or 5) steals an item of scientific, artistic or historical significance or importance to technological development found in a public collection or on public display; or 6) steals by taking advantage of someone's helplessness or an accident or other danger; or 7) steals a firearm for which a permit is necessary, or a machine gun, or a fully or semi- 
automatic rifle, or explosive weapon of war (as defined by the War Weapons Control Law).

- Theft with Weapons, Gang Theft: (\$244 StGB) theft in which: 1) the perpetrator or other participant carries a firearm; or 2) the perpetrator or other participant carries a weapon or other tool or item to prevent or overcome the resistance of another through force or the threat of force; or 3) the perpetrator, as a member of a gang formed to steal and rob, steals with the assistance of another gang member.

- Serious Gang Theft: ( $\$ 244 \mathrm{a} \mathrm{StGB})$ theft in which the perpetrator, as a member of a gang formed to steal and rob, with the assistance of another gang member meets the requirements of $\S 243$ paragraph 1, part 2 StGB or $\$ 244$ paragraph 1, number 1 or 2 , StGB.

\section{Fraud}

- Fraud: ( $\$ 263 \mathrm{StGB})$ the acquisition of someone else's property for one's own illegal enrichment or that of a third party by deception or by suppression of true facts.

- Computer Fraud: (\$263a StGB) the acquisition of someone else's property for one's own illegal enrichment or that of a third party through the results of a computerized process by means of the incorrect creation of a programme, the use of inaccurate or incomplete data, the unauthorized use of data, or the unauthorized influence on the course of a computerized process.

- Subsidy Fraud: ( $\$ 264$ StGB) the acquisition of subsidies by reporting deceptive, incorrect, or incomplete facts or by withholding information. The abuse of office or assistance through the abuse of office is considered Serious Subsidy Fraud. Subsidies are payments out of public moneys to businesses or entrepreneurs which are based on Federal, State, or European Community Rights and are in part granted without an exchange of services and are meant to promote the economic activity.

- Investment Fraud: ( $\$ 264 \mathrm{a} \mathrm{StGB}$ ) the misrepresentation of material facts or the withholding of negative material facts necessary to the investment decision in prospectuses, presentations, or overviews in the sales and offerings of stocks, options, or shares which allow the participation in the results of a company.

- Insurance Fraud: ( $\$ 265$ StGB) the intentional, fraudulent damage to a fire insured property through arson or to an insured ship or its cargo through sinking or beaching.

- Fraudulent Acquisition of Services: (\$265a StGB) the acquisition of the services of a vending machine or of public broadcasting installations or of public transportation or of entry to an event or exhibit without payment.

- Credit Fraud: ( $\$ 265 b$ StGB) the misrepresentation of business facts or the use of false or incomplete information in order to obtain credit for a business. 


\section{Vandalism (Damage to Property)}

- Vandalism: ( $\$ 303 \mathrm{StGB})$ the illegal damage to or destruction of someone else's property.

- Data Manipulation: ( $\$ 303 a \mathrm{StGB})$ the illegal erasure, suppression, change, or making unusable of data.

- Computer Sabotage: ( $\$ 303 \mathrm{~b} \mathrm{StGB)} \mathrm{the} \mathrm{disruption} \mathrm{of} \mathrm{data} \mathrm{processing} \mathrm{that} \mathrm{is} \mathrm{of}$ considerable significance to someone else's firm, business, or office through illegal erasure, suppression, change, or making unusable of data.

- Claims: ( $\$ 303 \mathrm{c}$ StGB) the crimes described in sections 303 to $303 \mathrm{~b}$ are only prosecuted if a claim is filed, unless the prosecutor finds a particular public interest in pursuing the case.

- Vandalism of Public or Community Property: ( $\$ 304$ StGB) the illegal damage to or destruction of: items in tribute to a state-recognized church or items used in religious services; or grave markers, public monuments, natural monuments; or artistic, scientific, or trade works which are part of public collections or public exhibits; or items meant to serve the public good or the beautification of public paths, places, or parks.

- Destruction of Public Works or Buildings: (\$305 StGB) the illegal complete or partial destruction of a building, bridge, dam, paved road, railway, or other structure which is someone else's property. 


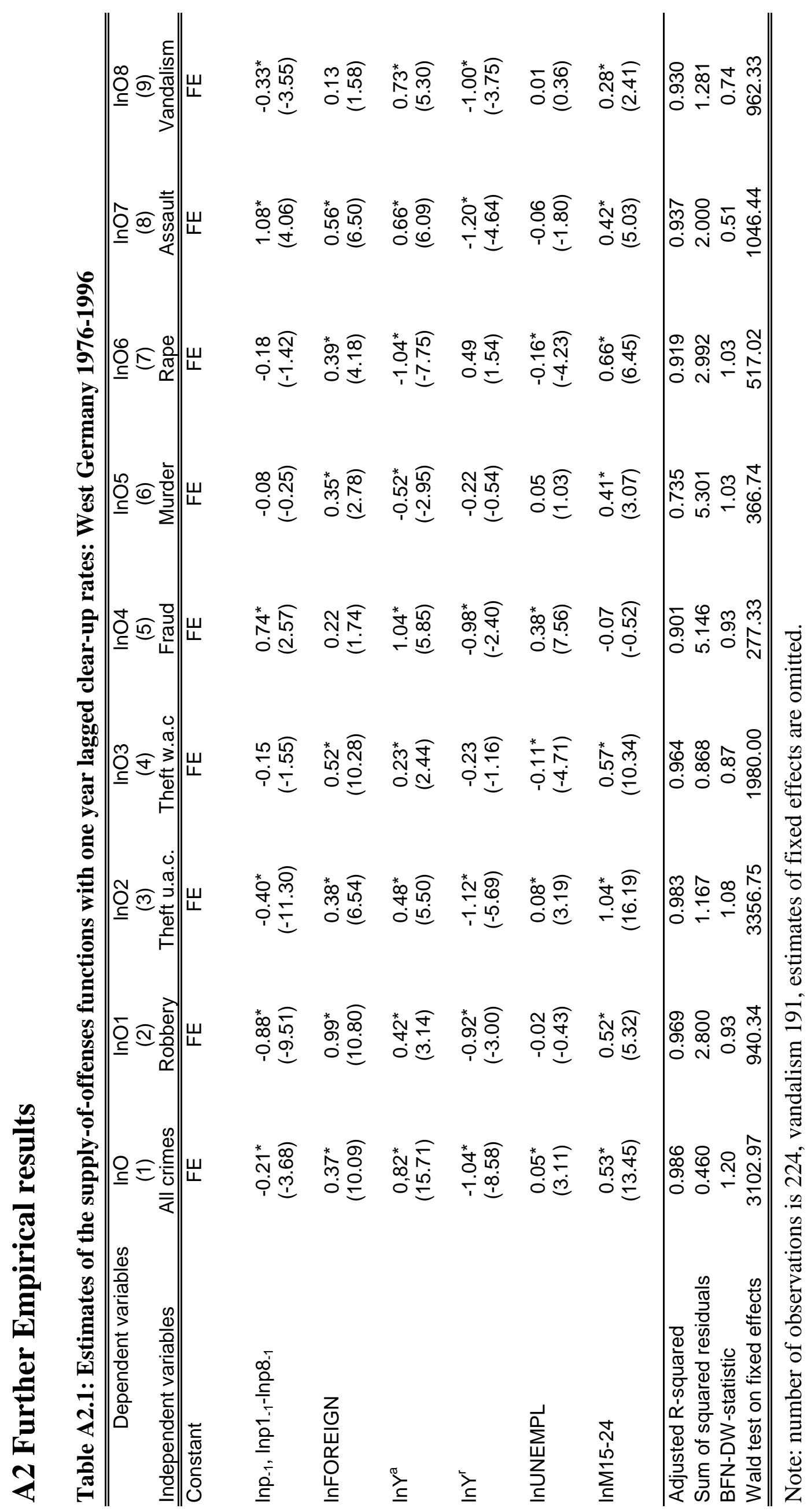




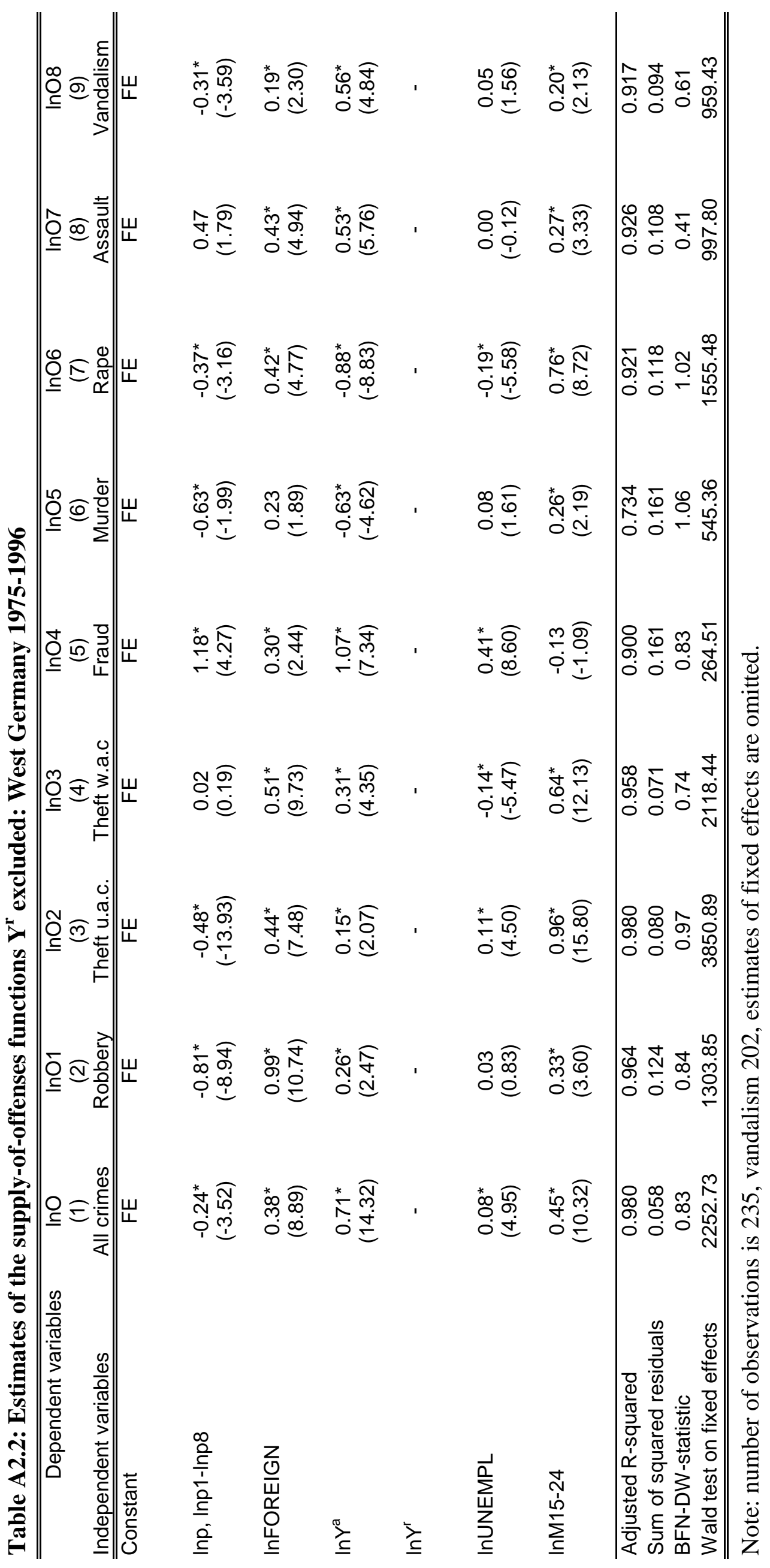




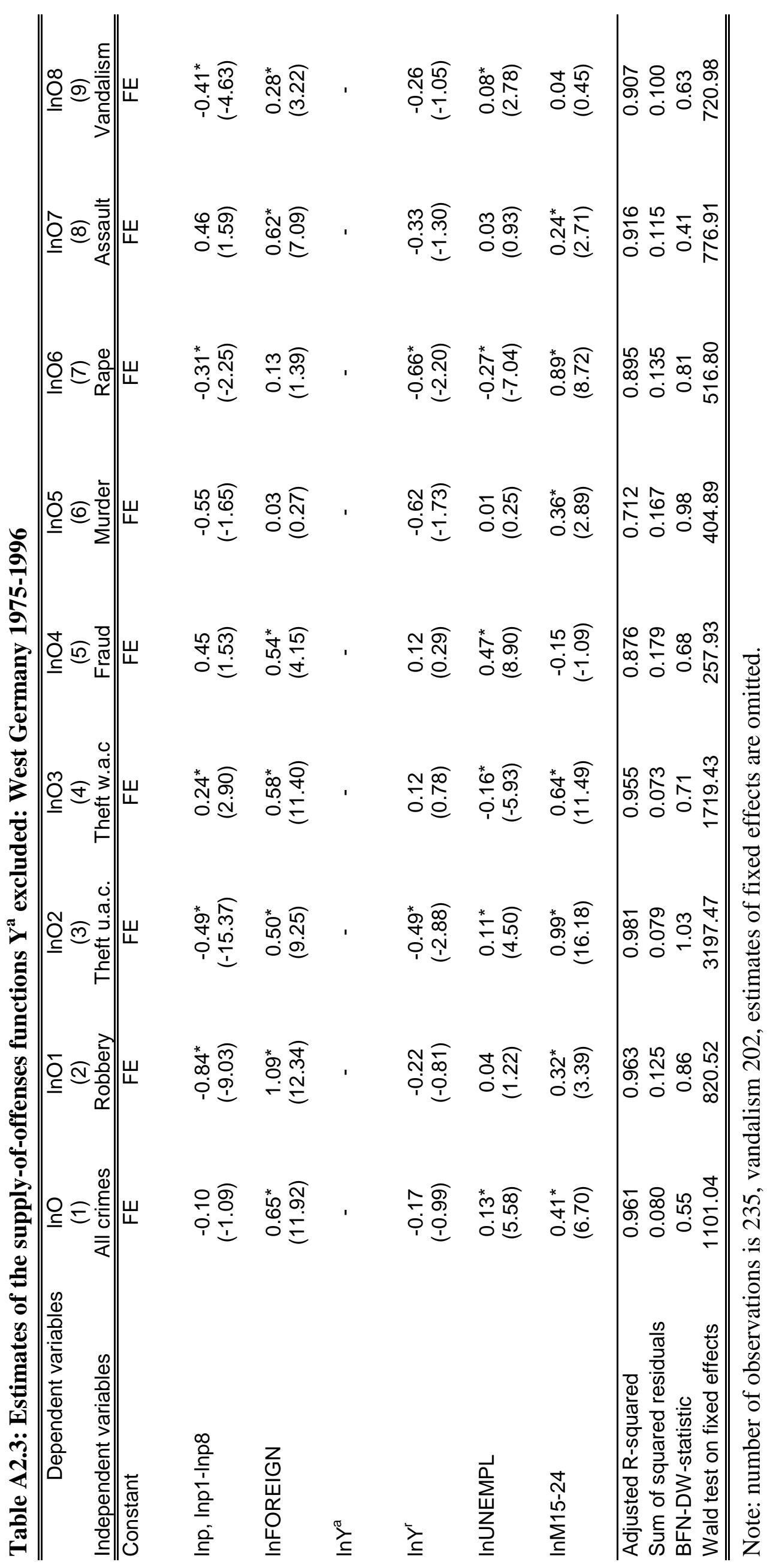




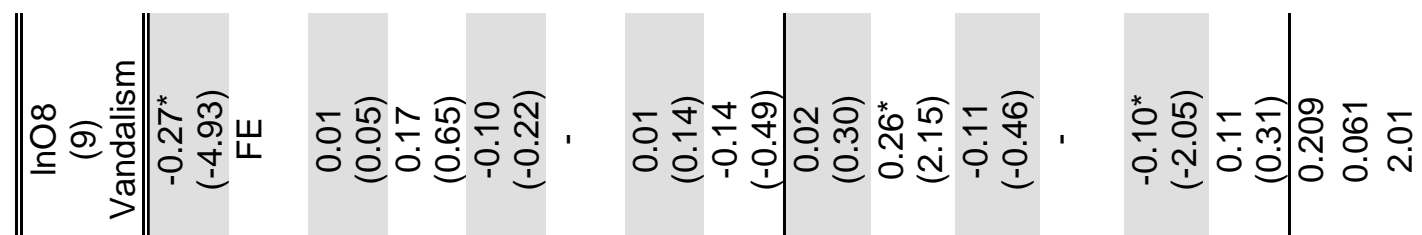

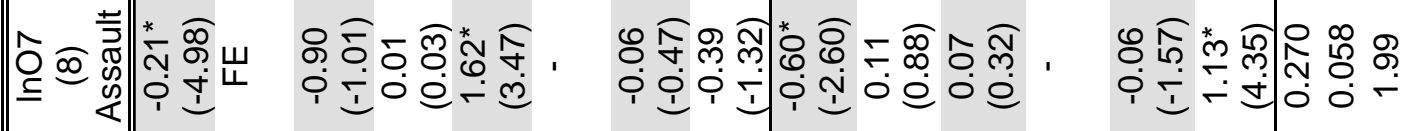

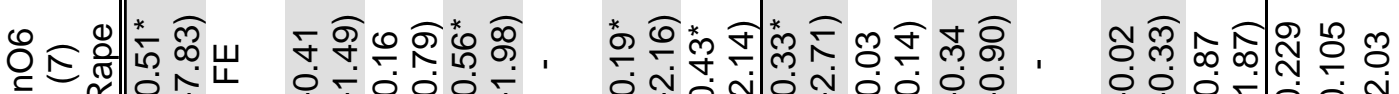

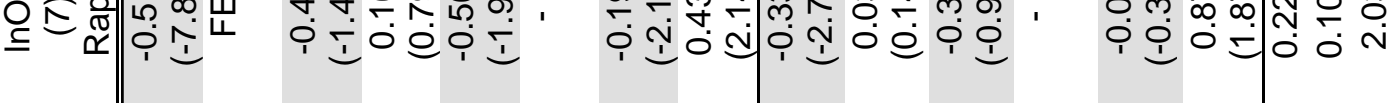

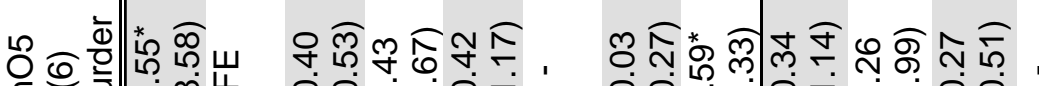

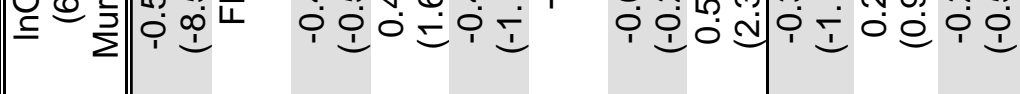

웡유유요

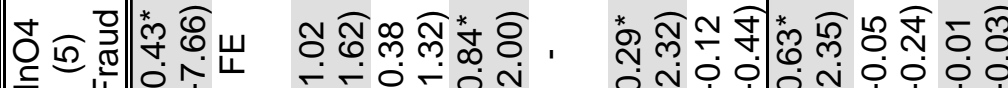

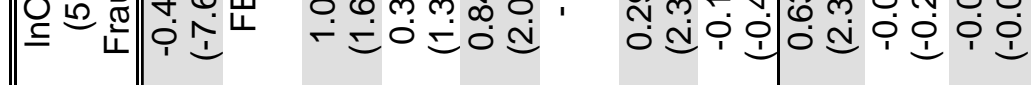

凤

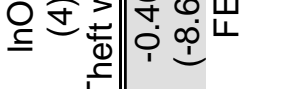

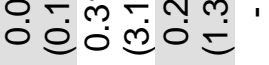

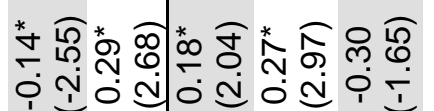

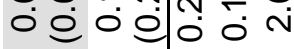

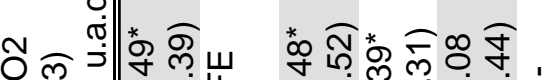

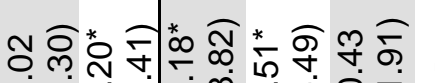

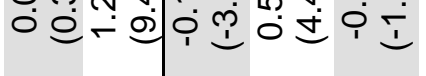

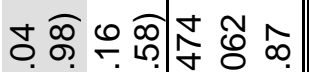
00000 우운

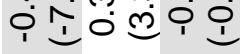

치유.

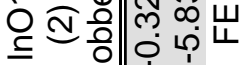

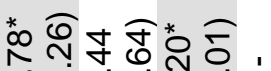

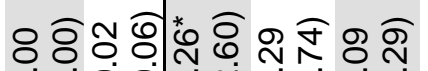

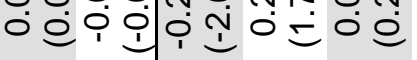

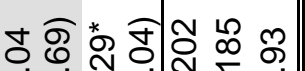
०0రి Oํㅣ윙ㅇㅇ 옹ำ

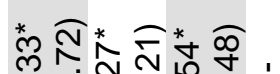

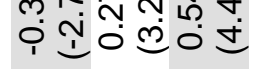

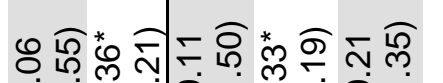

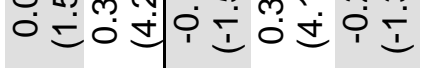

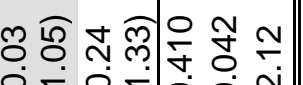
$0=0=0$ ○े 잔
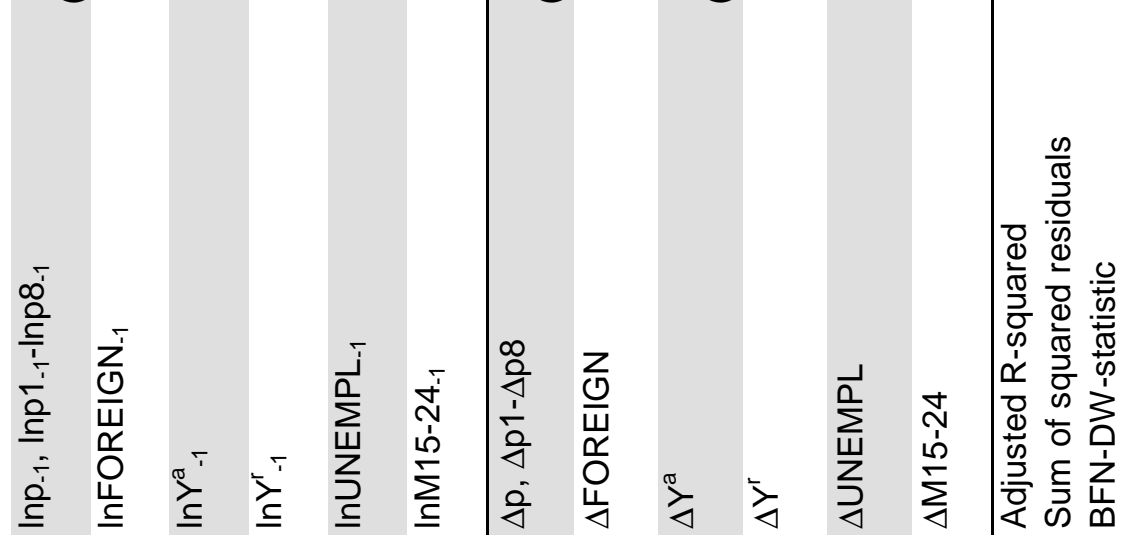


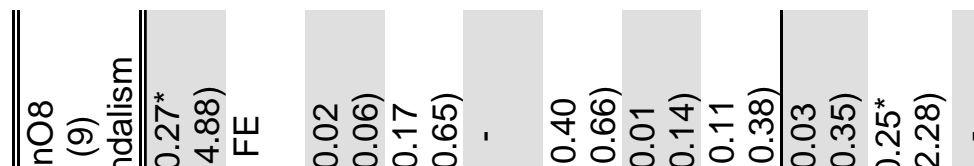

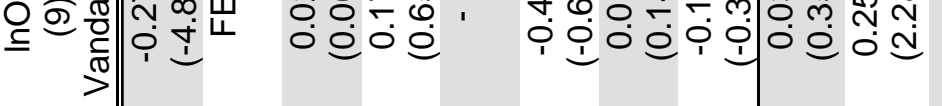

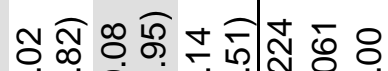
$0=0,100000$

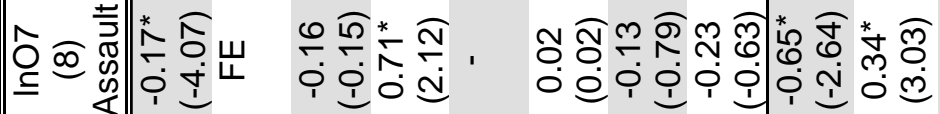

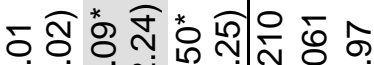

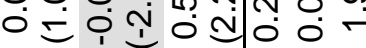

ஜํำ

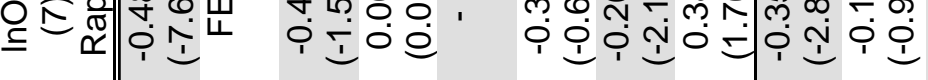

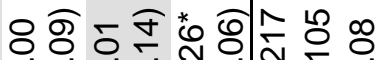

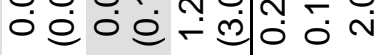

○ी

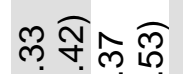

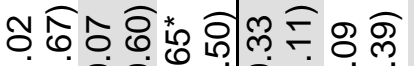

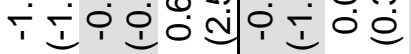

ธ。์ 엉ำ

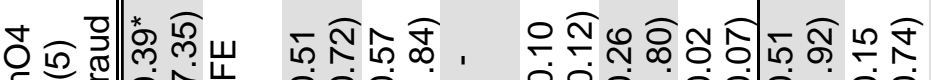

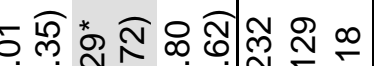
i Lا山i

i

(ن)

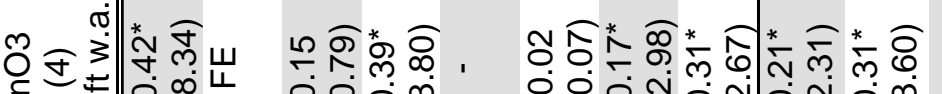

중

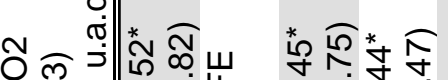

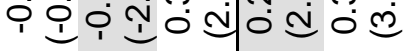

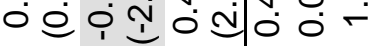

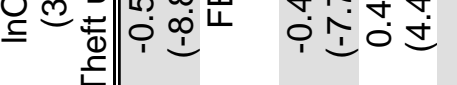

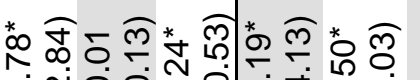

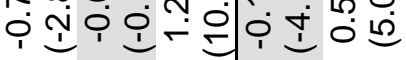

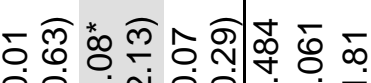

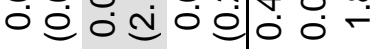

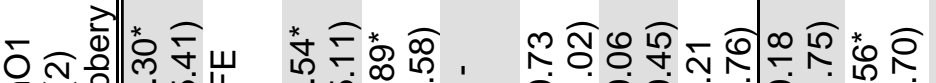

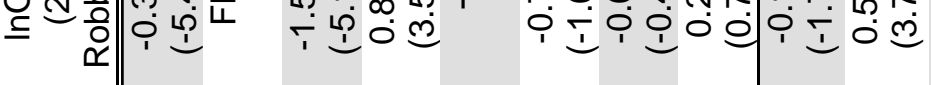

ธิ ำ 00000

\&

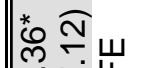

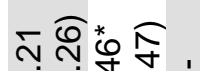

ஸे

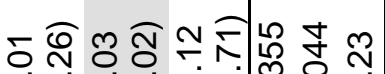
$0=0$ E 1 i ?ृ.
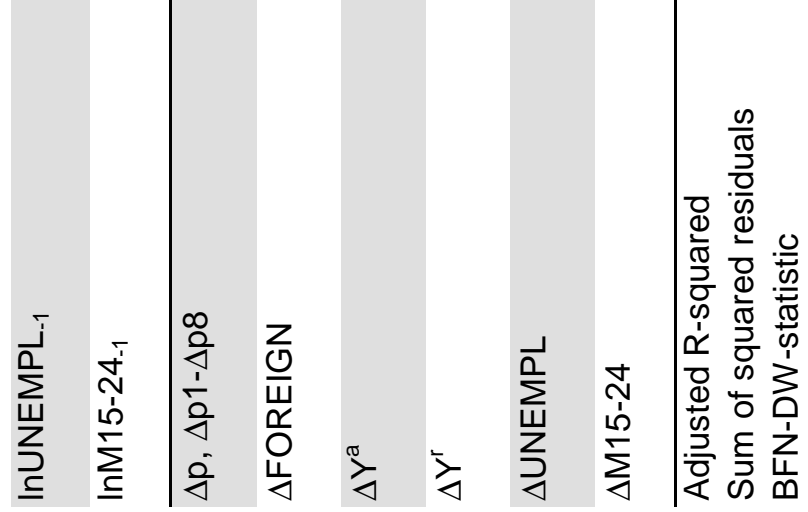


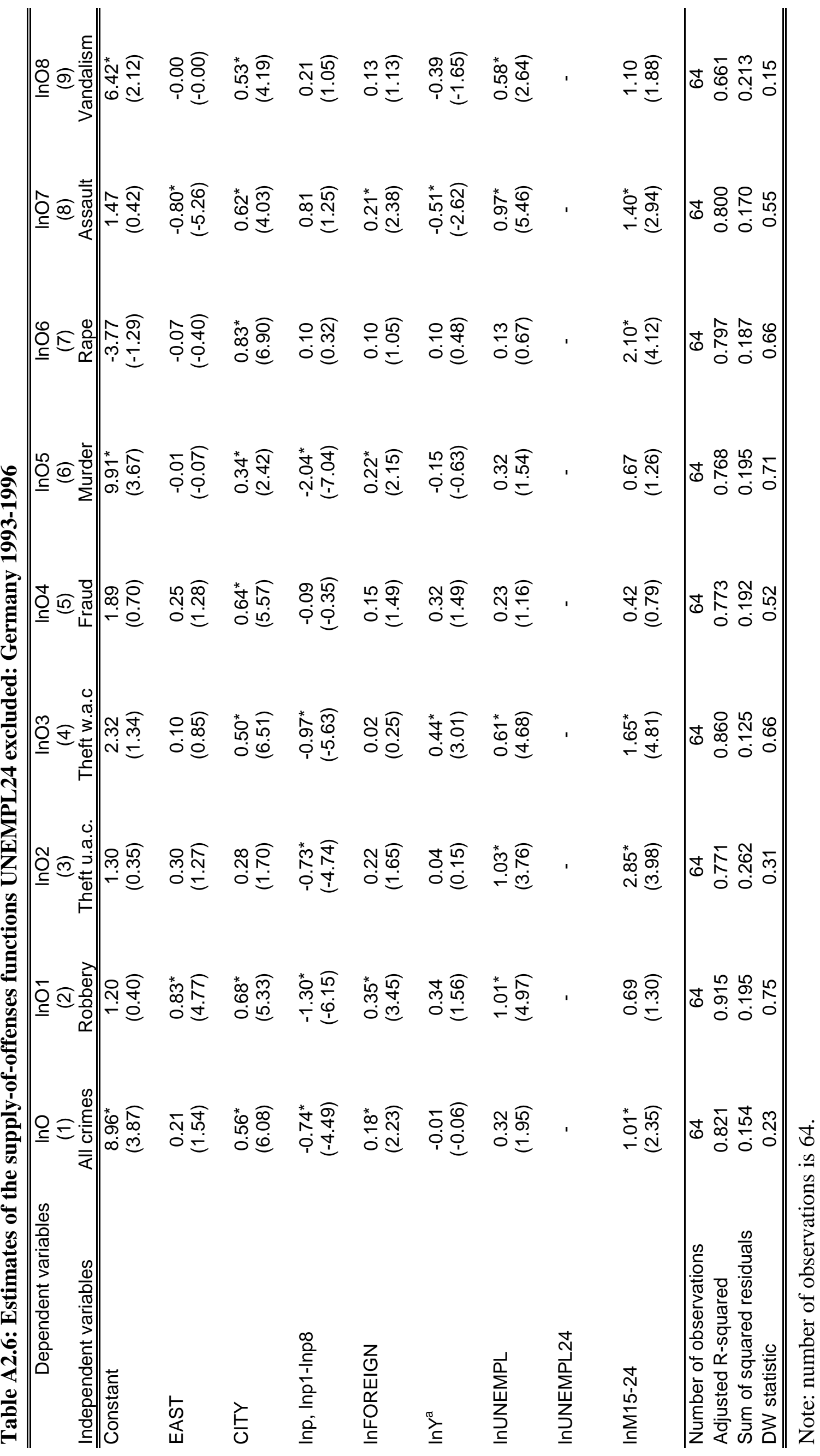


Table A2.7: Panel unit root tests

\begin{tabular}{|c|c|c|c|c|}
\hline \multirow[b]{2}{*}{ Variables } & \multicolumn{2}{|c|}{$\begin{array}{c}\text { Inclusion of an aggregate } \\
\text { intercept }\end{array}$} & \multicolumn{2}{|c|}{$\begin{array}{l}\text { Inclusion of state-specific } \\
\text { intercepts }\end{array}$} \\
\hline & DF-tests & ADF(1)-tests & DF-tests & ADF(1)-tests \\
\hline $\mathrm{O}$ & $-2,37^{*}$ & $-2,04$ & $-8,89^{*}$ & $-8,81^{*}$ \\
\hline O1 & $-4,30^{*}$ & $-2,57^{*}$ & $-8,30^{*}$ & $-5,47^{\star}$ \\
\hline $\mathrm{O} 2$ & $-1,17$ & $-0,31$ & $-4,18$ & $-2,40$ \\
\hline O3 & 1,21 & 0,99 & $-1,93$ & $-2,84$ \\
\hline O4 & $-2,11^{*}$ & $-2,15^{*}$ & $-5,18$ & $-5,93^{*}$ \\
\hline O5 & $-0,84$ & $-1,26$ & $-7,25^{*}$ & $-7,67^{*}$ \\
\hline $\mathrm{O} 6$ & $-1,89$ & $-1,48$ & $-9,64^{*}$ & $-9,04^{*}$ \\
\hline $\mathrm{O} 7$ & $-3,07^{*}$ & $-2,59^{*}$ & $-5,25$ & $-4,37$ \\
\hline $\mathrm{O} 8$ & $-2,26^{*}$ & $-2,09^{*}$ & $-6,79^{*}$ & $-7,14^{*}$ \\
\hline$p$ & $-1,89$ & $-1,54$ & $-6,10^{*}$ & $-5,91^{*}$ \\
\hline $\mathrm{p} 1$ & $-9,39^{*}$ & $-6,18^{*}$ & $-11,93^{*}$ & $-8,73^{*}$ \\
\hline p2 & $-6,39^{*}$ & $-3,58^{*}$ & $-9,51^{*}$ & $-5,64^{*}$ \\
\hline p3 & $-3,18^{*}$ & $-1,91$ & $-6,51^{*}$ & $-5,26$ \\
\hline p4 & $-1,67$ & $-1,58$ & $-4,45$ & $-4,65$ \\
\hline p5 & $-2,04$ & $-1,82$ & $-4,17$ & $-3,81$ \\
\hline p6 & $-3,04^{*}$ & $-2,65^{*}$ & $-3,58$ & $-3,26$ \\
\hline p7 & $-3,12^{*}$ & $-2,59^{*}$ & $-3,64$ & $-3,22$ \\
\hline p8 & $-3,95^{*}$ & $-3,69^{*}$ & $-6,02^{*}$ & $-5,50^{*}$ \\
\hline FOREIGN & 0,66 & $-0,47$ & 1,18 & $-0,84$ \\
\hline$Y^{a}$ & $-3,10^{*}$ & $-1,56$ & $-6,31^{*}$ & $-4,02$ \\
\hline$Y^{r}$ & $-0,24$ & $-0,22$ & 0,58 & 0,44 \\
\hline UNEMPL & $-2,64^{*}$ & $-5,29^{*}$ & $-3,43$ & $-6,64^{*}$ \\
\hline M15-24 & 3,73 & $-7,01^{*}$ & 5,04 & $-7,72^{*}$ \\
\hline
\end{tabular}

Note: * represents significance at the 5\% level, critical values are taken from Levin and Lin (1992). 


\section{References}

Akerlof, G. A., Social Distance and Social Decisions, in: Econometrica 65, (1997), 1005-1027.

Becker, G. S., Crime and Punishment: An Economic Approach, in: Journal of Political Economy 76 (1968), 169-217.

Bhargava, A., L. Franzini, W. Narendranathan, Serial correlation and fixed effects model, in Review of Economic Studies 58 (1982), 129-140.

Brantingham, P., T. Easton, The Crime Bill: Who Pays and How Much?, Fraser Forum, 1996.

Bundesanstalt für Arbeit, Jahreszahlen (various issues), Nürnberg.

Bundesanstalt für Arbeit, Strukturanalyse (various issues), Nürnberg.

Bundeskriminalamt, Polizeiliche Kriminalstatistik (various issues), Wiesbaden.

DiIulio, Jr. J. J., Help Wanted: Economists, Crime and Public Policy, in: Journal of Economic Perspectives 10 (1996), 43-67.

Ehrlich, I., Participation in Illegitimate Activities: A Theoretical and Empirical Investigation, in: Journal of Political Economy 81 (1973), 521-565.

Ehrlich I., Crime, Punishment, and the Market for Offenses, in: Journal of Economic Perspectives 10 (1996), 43-67.

Eide, E., Economics of Crime: Deterrence and the Rational Offender, Amsterdam: North-Holland, 1994.

Eide, E., Economics of Criminal Behavior: Survey and Bibliography, Working Paper Law and Economics C No 5, Institutt for privatrett, Universitetet i Oslo, 1997.

Entorf, H., Kriminalität und Ökonomie: Übersicht und neue Evidenz, in: Zeitschrift für Wirtschafts- und Sozialwissenschaften 116 (1996), 417-450.

Entorf, H., Ökonomische Theorie der Kriminalität, Paper prepared for the $6^{\text {th }}$ "Travemünder Symposium zur Ökonomischen Analyse des Rechts", mimeo, University of Würzburg, 1998.

Freeman, R.B., Why Do So Many Young American Men Commit Crimes and What Might We Do About It? in: Journal of Economic Perspectives 10 (1996), 25-42. 
Glaeser, E.L., B. Sacerdote, Why is there more Crime in Cities?, NBER Working Paper No. 5430 (1996).

Glaeser, E.L., B. Sacerdote, J.A. Scheinkman, Crime and Social Interactions, in: Quarterly Journal of Economics 111 (1996), 507-548.

Grogger, J., The Effect of Arrest on the Employment and Earnings of Young Men, in: Quarterly Journal of Economics 110 (1995), 51-72.

Grogger, J., Market Wages and Youth Crime, NBER Working Paper No. 5983 (1997).

Levin, A., C.-F. Lin, Unit Root Tests in Panel Data: Asymptotic and Finite-Sample, Discussion Paper 92-93, Department of Economics, University of California, San Diego, 1992.

Levin, A., C.-F. Lin, Unit Root Tests in Panel Data: New Results, Discussion Paper 93-56, Department of Economics, University of California, San Diego, 1993.

Pfeiffer, C., K. Brettfeld, I. Delzer, Kriminalität in Niedersachsen: Eine Analyse auf der Basis der Polizeilichen Kriminalstatistik 1988-1995, Kriminologisches Forschungsinstitut Niedersachsen, Forschungsbericht Nr. 56, 1996.

Ploeger, M., Youth Employment and Delinquency: Reconsidering a Problematic Relationship, Criminology 35 (1997), 659-675.

Williams, J., C.R. Sickles, The Role of Social Capital in Youth Crime: A Dynamic Structural Approach, (paper under revision, 1997).

Spengler, H., Sozioökonmische Ursachen und Wirkungen der Kriminalität in der Bundesrepublik Deutschland, Diplomarbeit, Fakultät für Volkswirtschaftslehre, Universität Mannheim, 1996.

Statistisches Bundesamt, Statistisches Jahrbuch (various issues), Wiesbaden.

Sutherland, E.H., D.R. Cressey, Criminology, $9^{\text {th }}$ ed., Philadelphia: J.B. Lippincott, 1974.

United Nations, United Nations Surveys of Crime Trends and Operations of Criminal Justice Systems, http://www.ifs.univie.ac.at/ uncjin/wcs.html.

Wolpin, K.I., An Economic Analysis of Crime and Punishment in England and Wales 1894-1967, in: Journal of Political Economy 86 (1978), 815-840. 